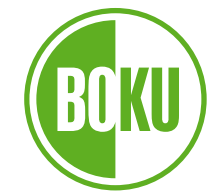

Universität für

Bodenkultur Wien

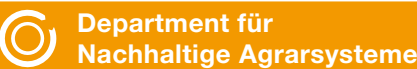

Institut für Ökologischen Landbau

\title{
Biokulturelle Vielfalt
}

Vom lokalen Erfahrungswissen zu Pflanzen

im Biosphärenpark Großes Walsertal

Susanne Grasser, Christian R. Vogl, Christoph Schunko,

Martina Melissa Grabowski, Traute Vogl, Brigitte Vogl-Lukasser

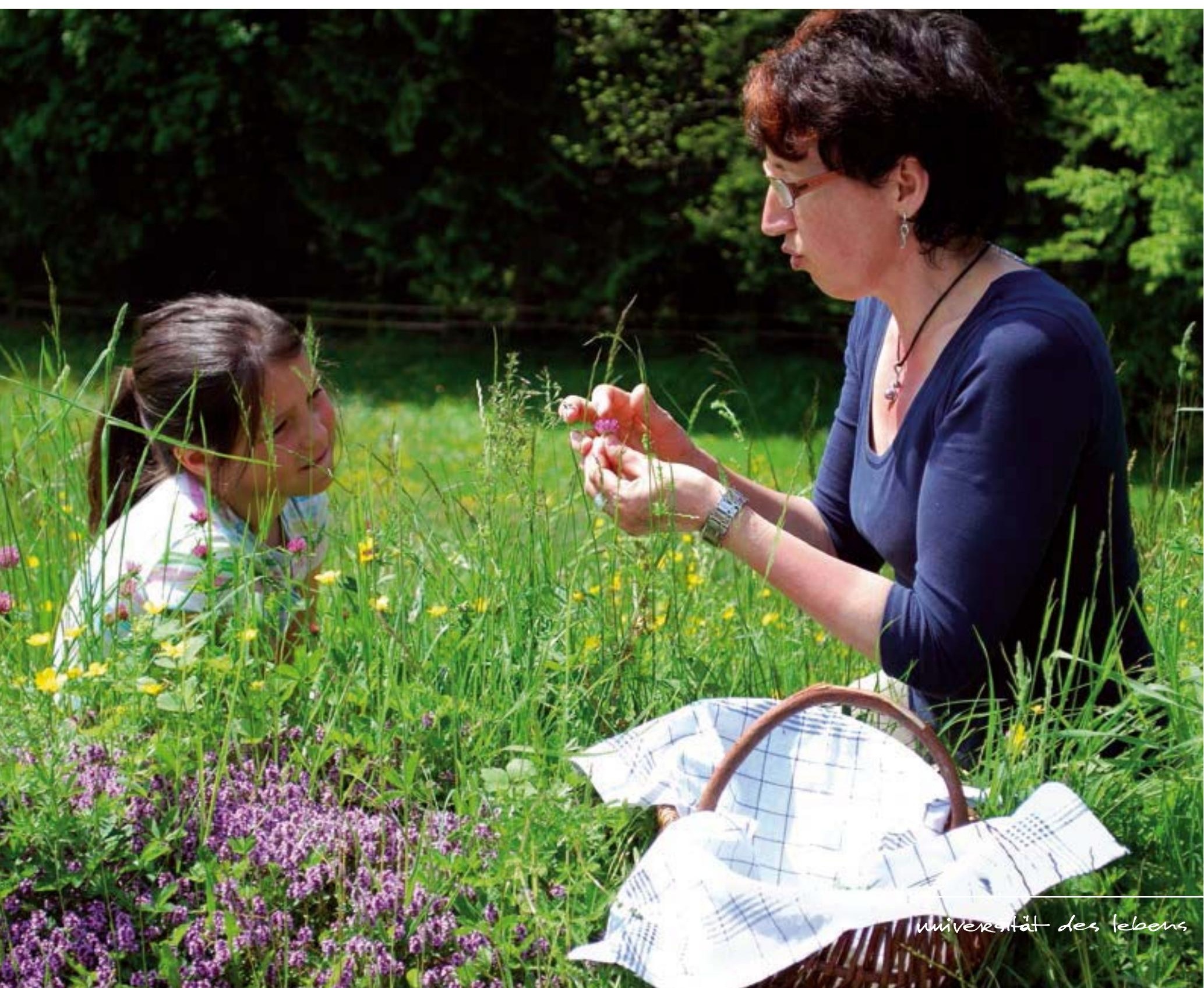




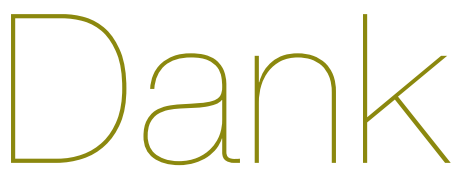

Ein herzliches Dankeschön an alle, die uns bei unserer Forschungsarbeit unterstützten. Insbesondere möchten wir uns bei allen GesprächspartnerInnen im Großen Walsertal für das Teilen ihres Wissens bedanken, allen voran Elisabeth Burtscher und Ilga Bickel vom Bergtee-Projekt.

Ein weiterer spezieller Dank gilt den Frauen vom Alchemilla-Projekt, insbesondere Susanne Türtscher, und Monika Hartmann für ihren immer offenen Garten. Wir danken all den engagierten Kindern für ihr begeistertes Mit-Forschen sowie den Volksschulen mit ihren Leiterlnnen, allen voran David Ganahl. Dem Management des Biosphärenparks, in Person Ruth Moser sowie dem gesamten Kuratorium, sei Dank für die freundliche Zusammenarbeit.

Der Filmemacherin Maria Weber sei gedankt für die großartige Kooperation im Partizipativen Video-Projekt mit den Kindern und die professionelle Umsetzung.

Wir danken dem Nationalkomitee für das UNESCO-Programm „Man and the Biosphere“ an der Österreichischen Akademie der Wissenschaften für die Förderung des Projektes. 

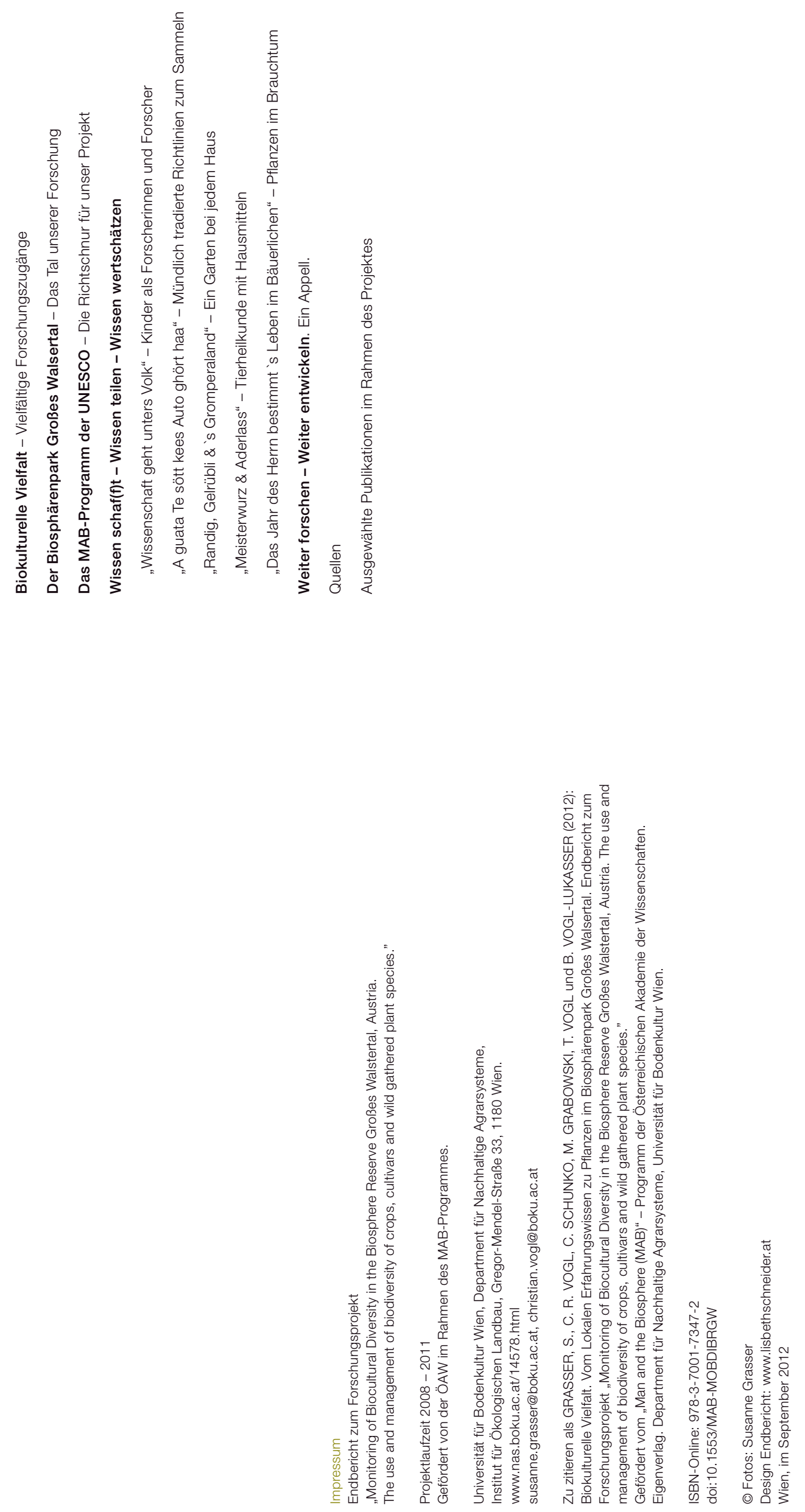

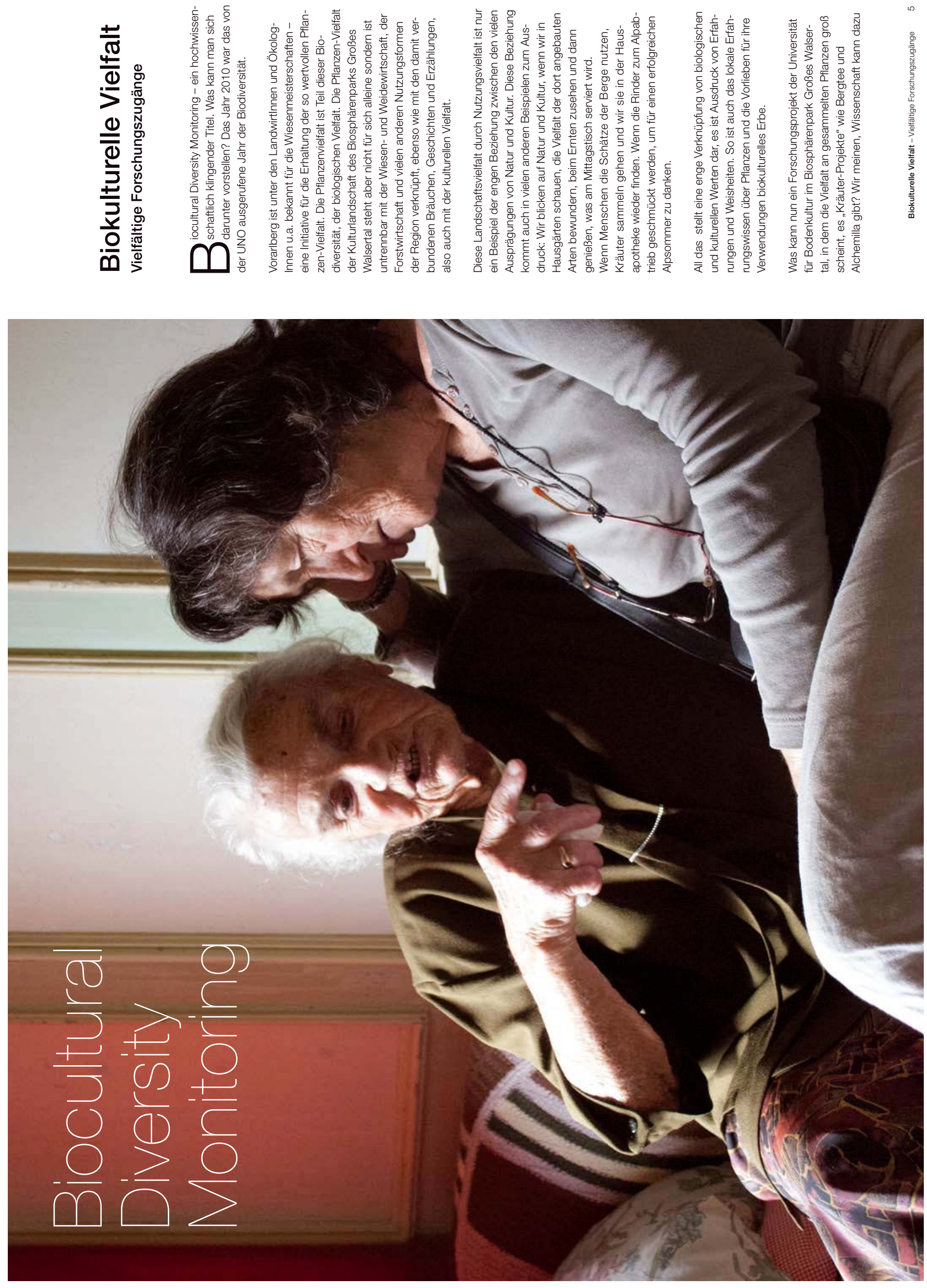


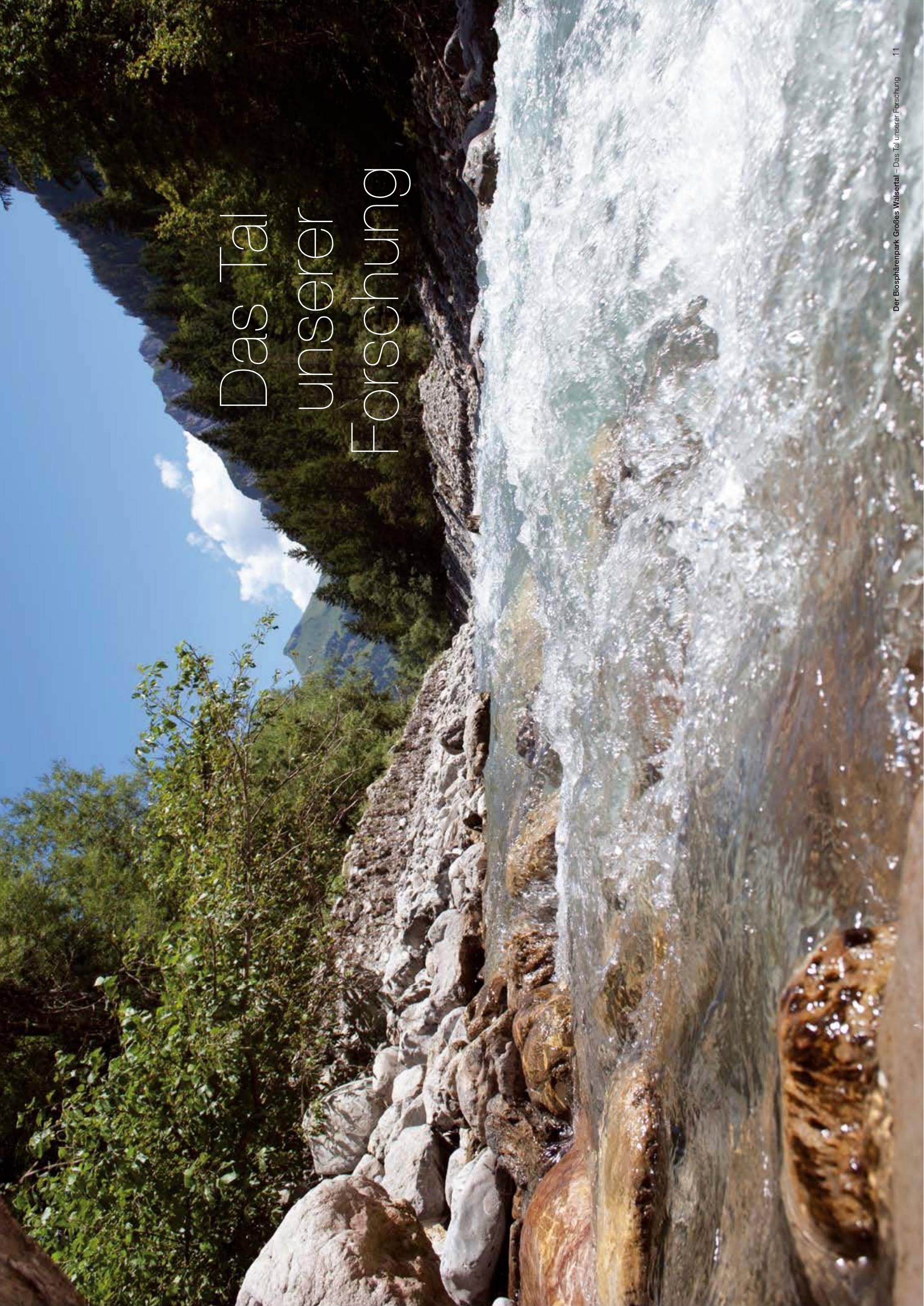



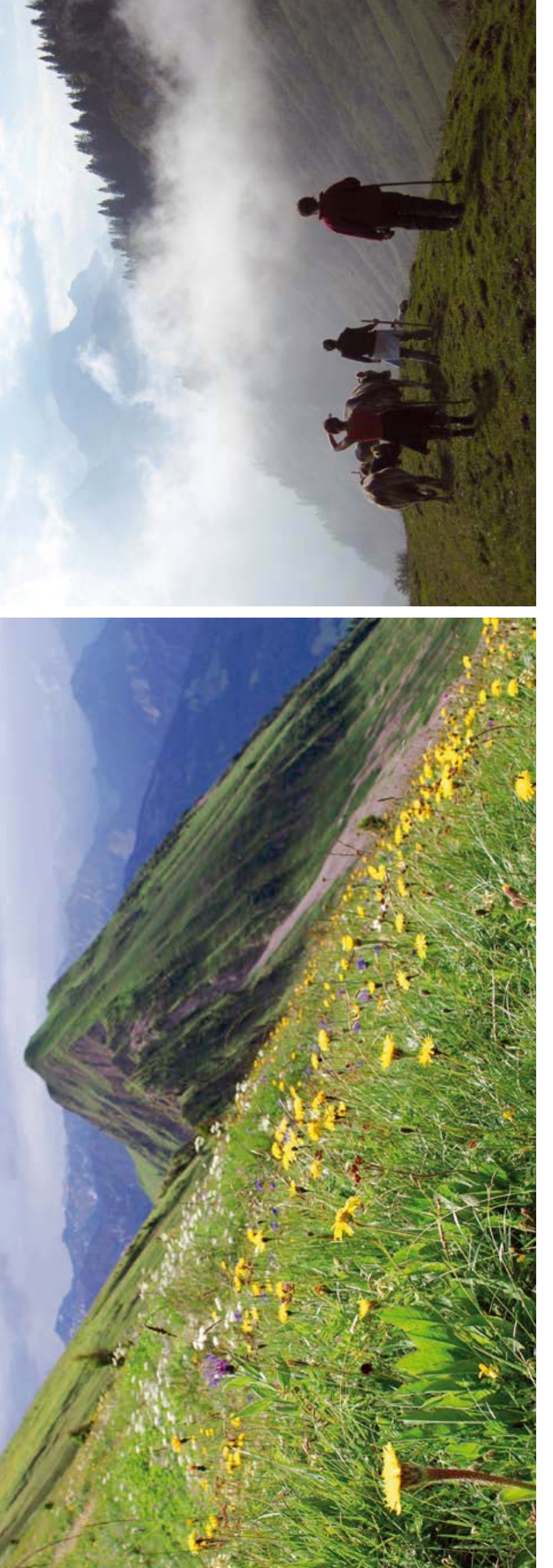

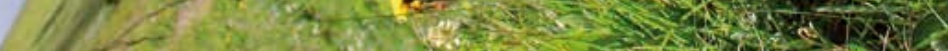

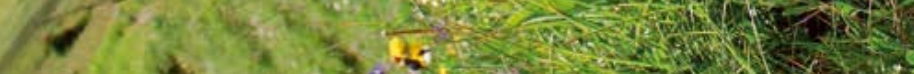

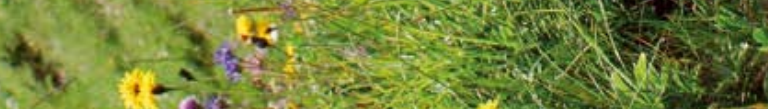

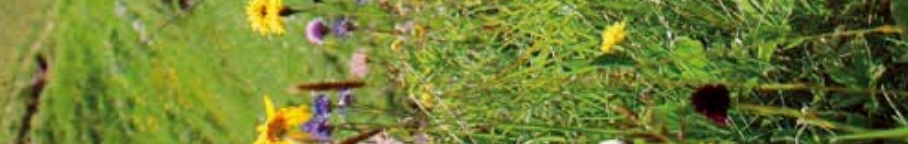

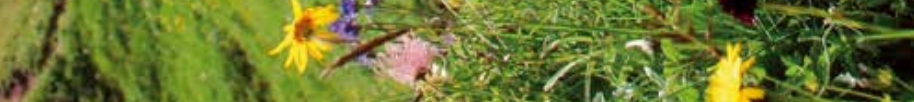
i. 35120 the

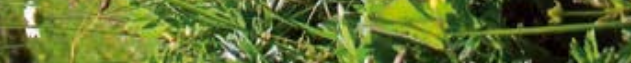

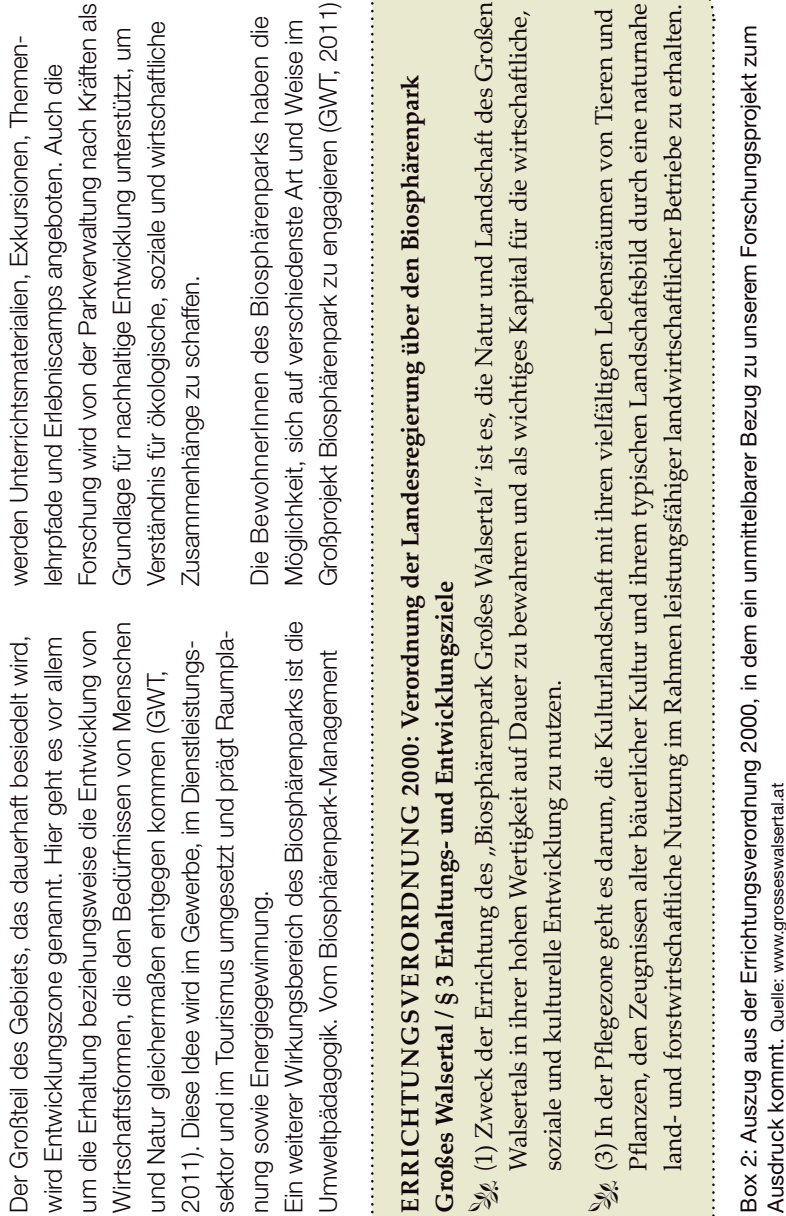

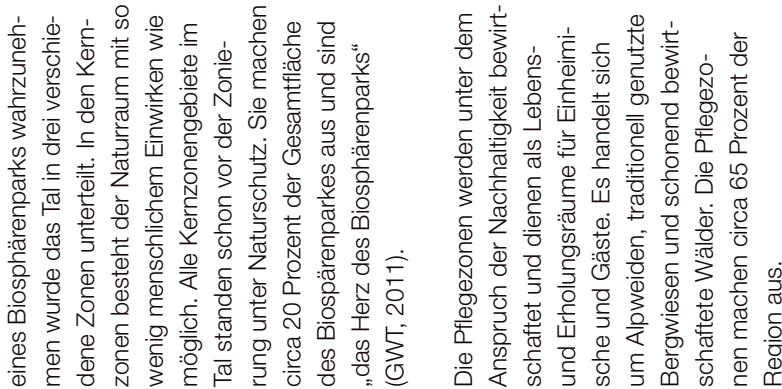




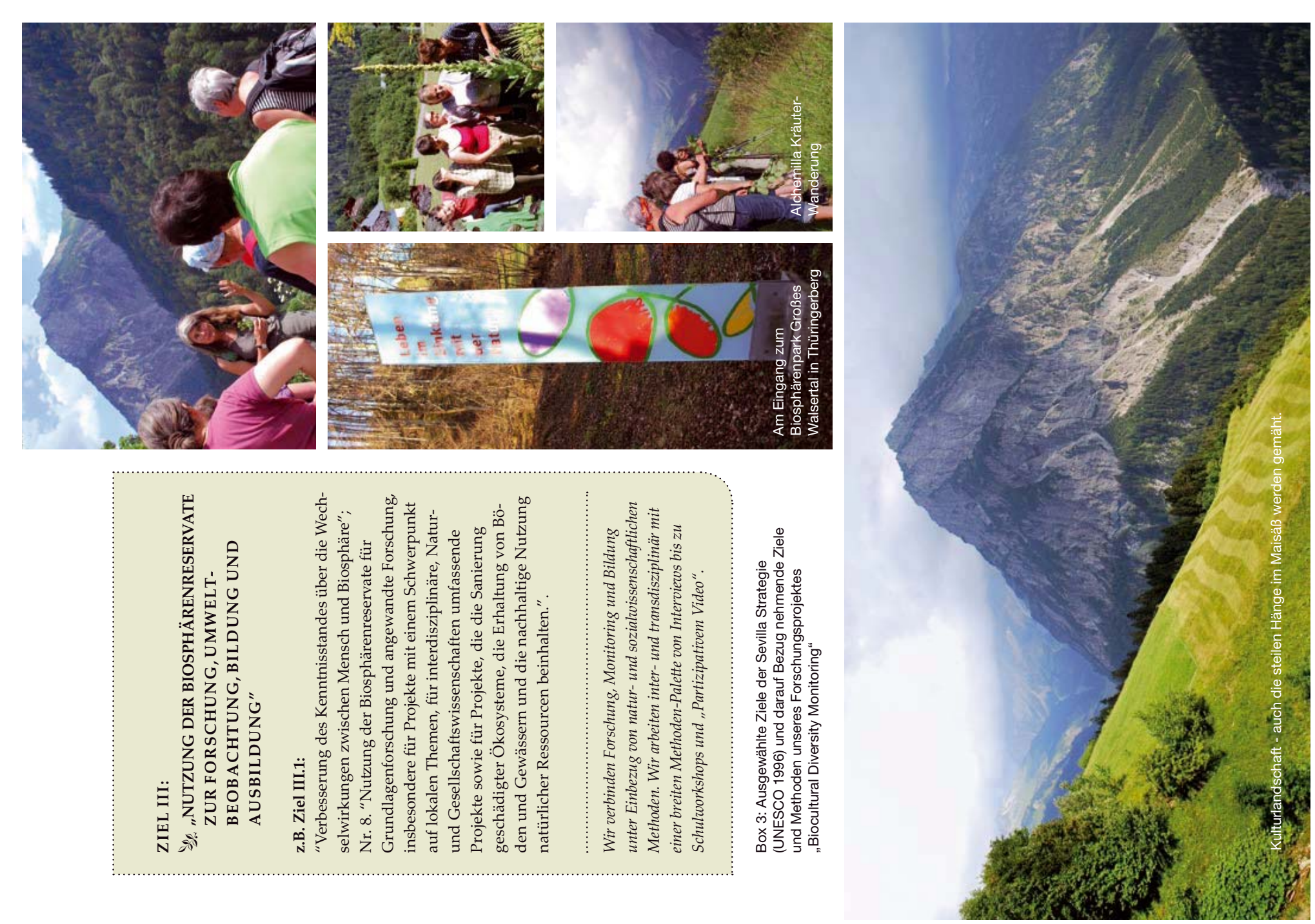

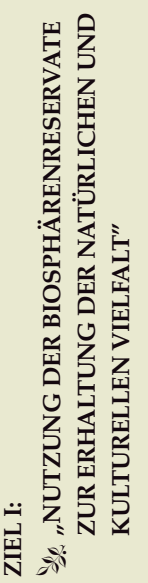
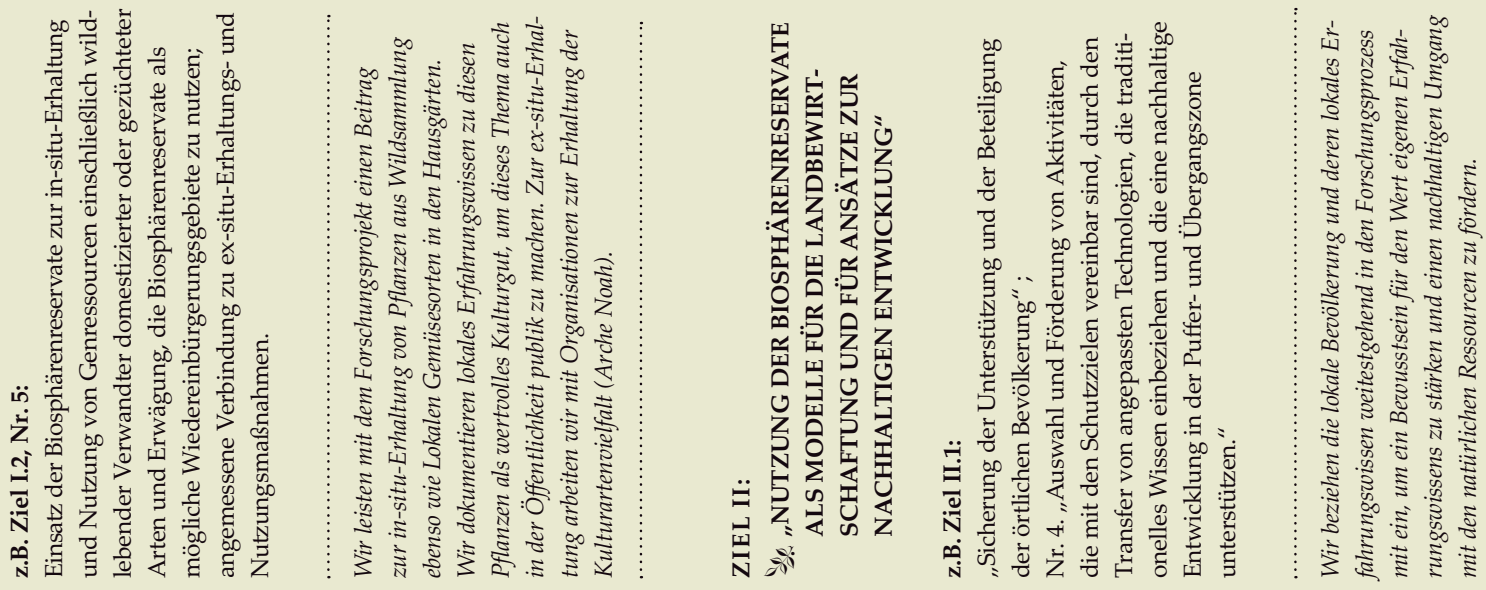

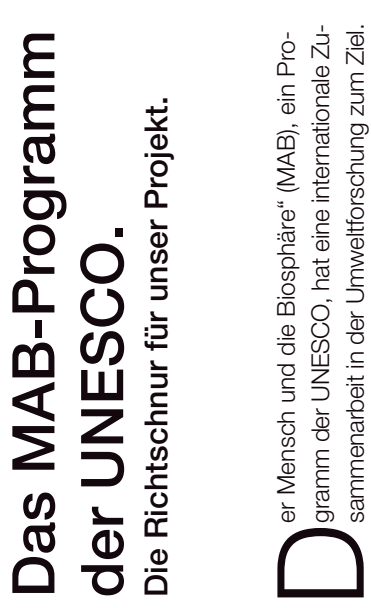

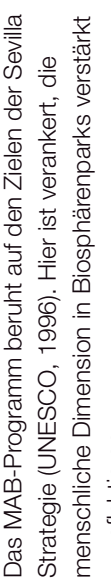
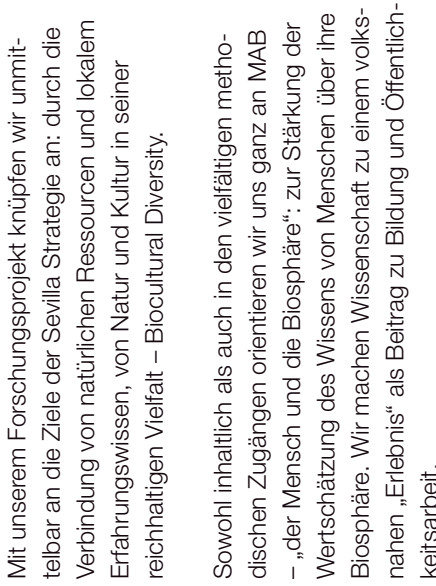

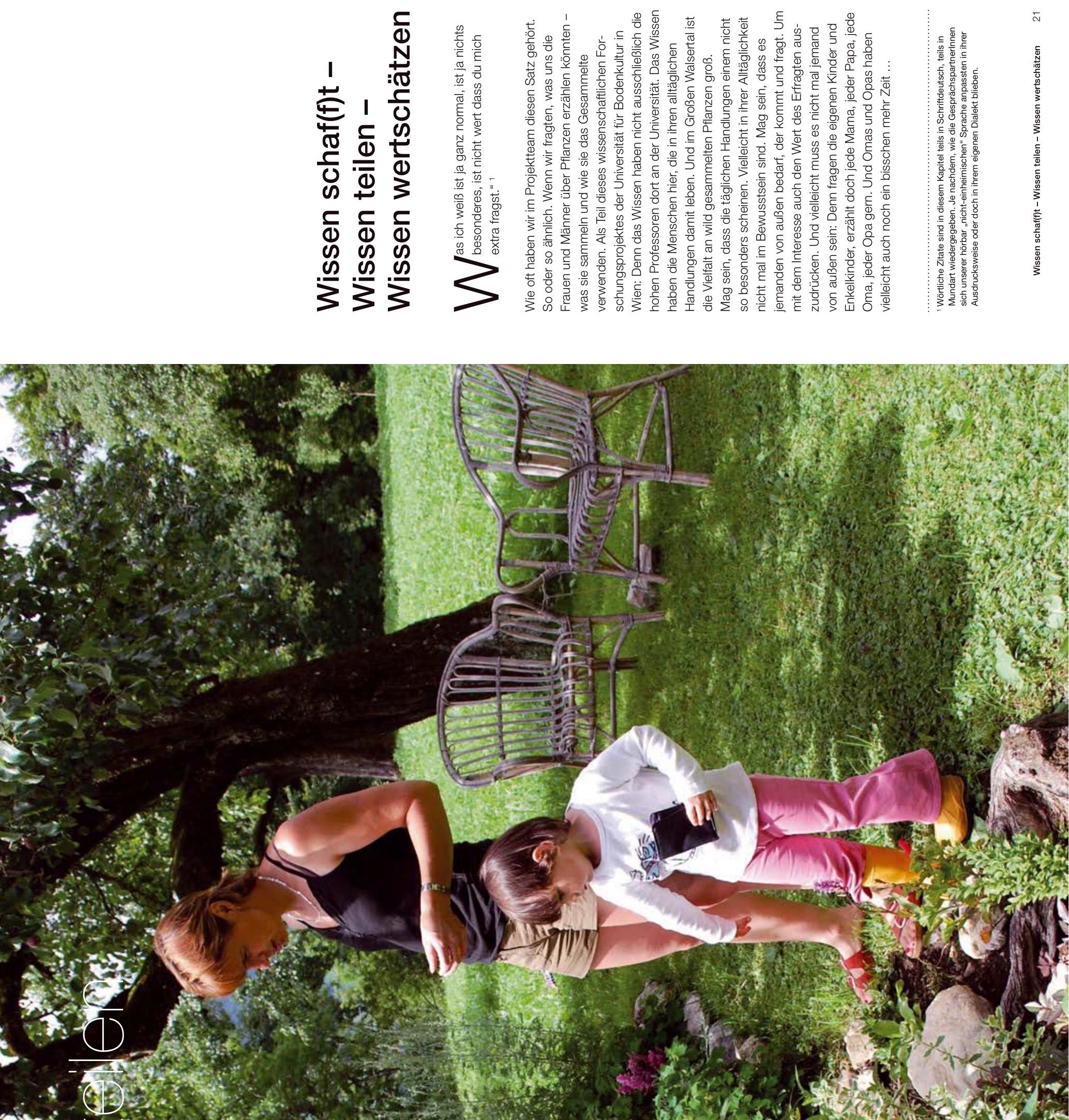

\section{a.}

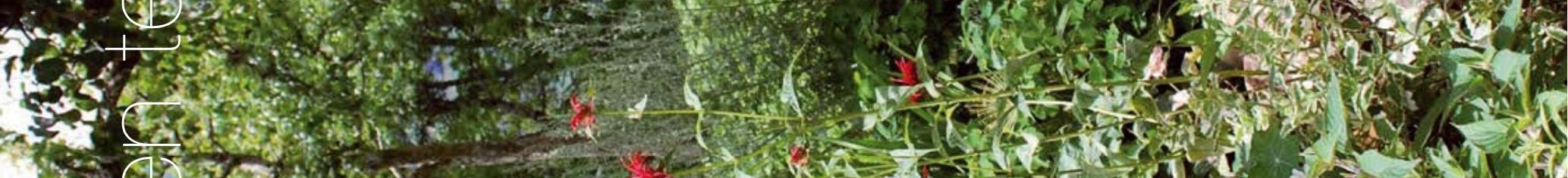

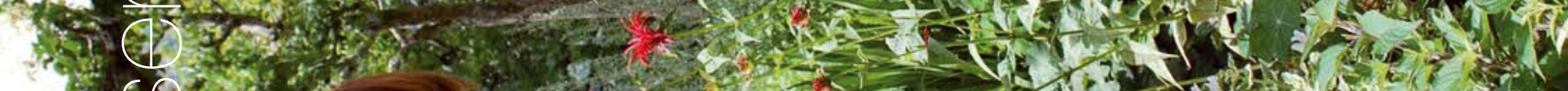

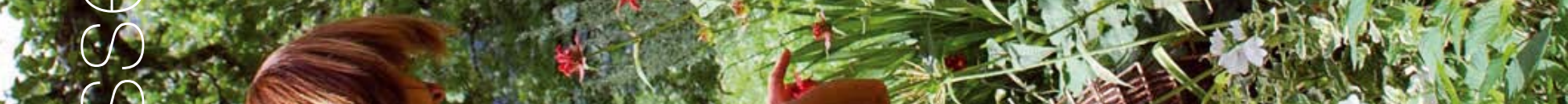

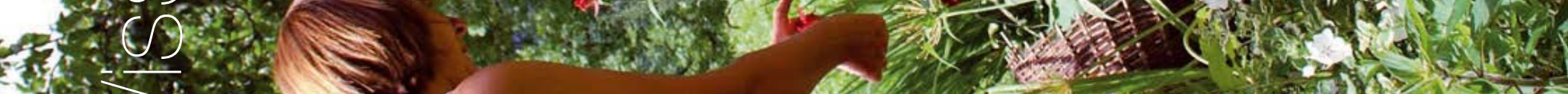

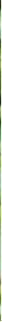



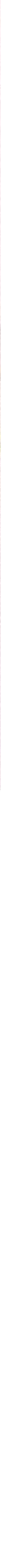

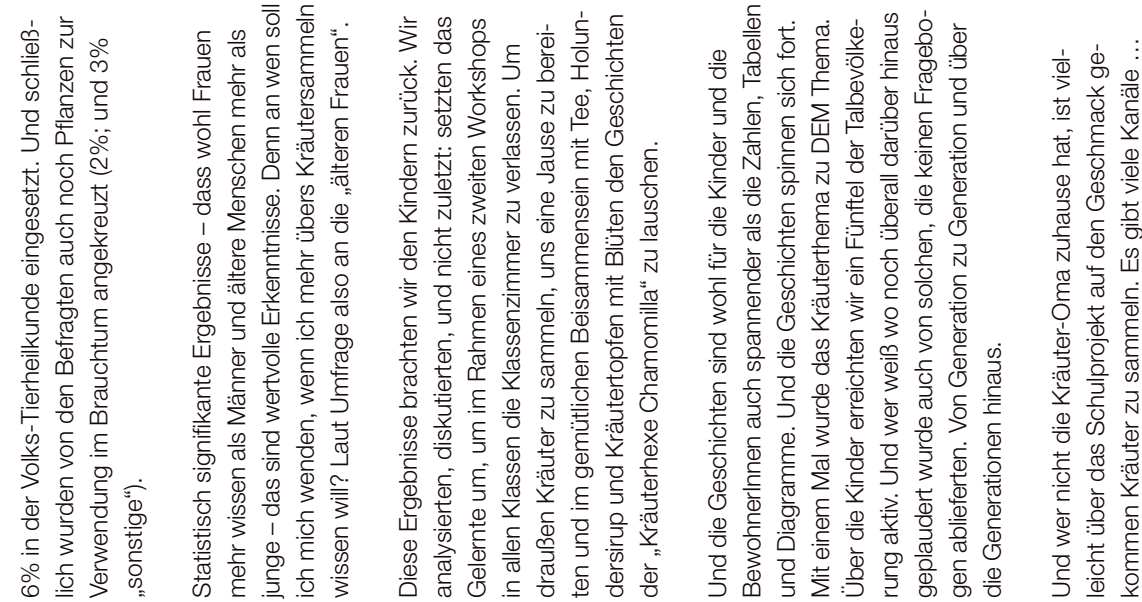

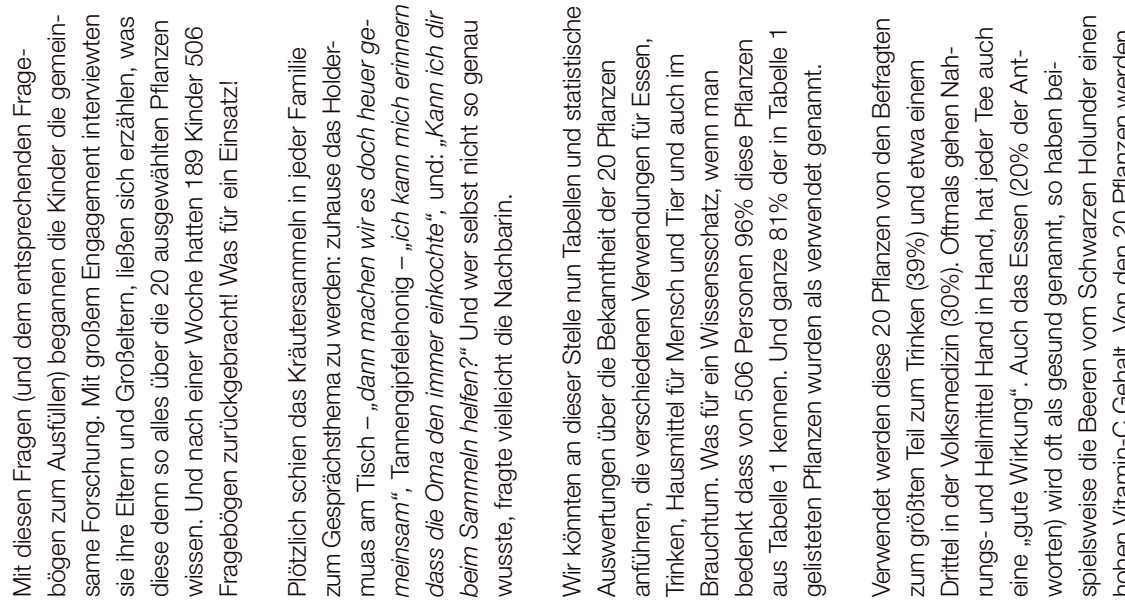



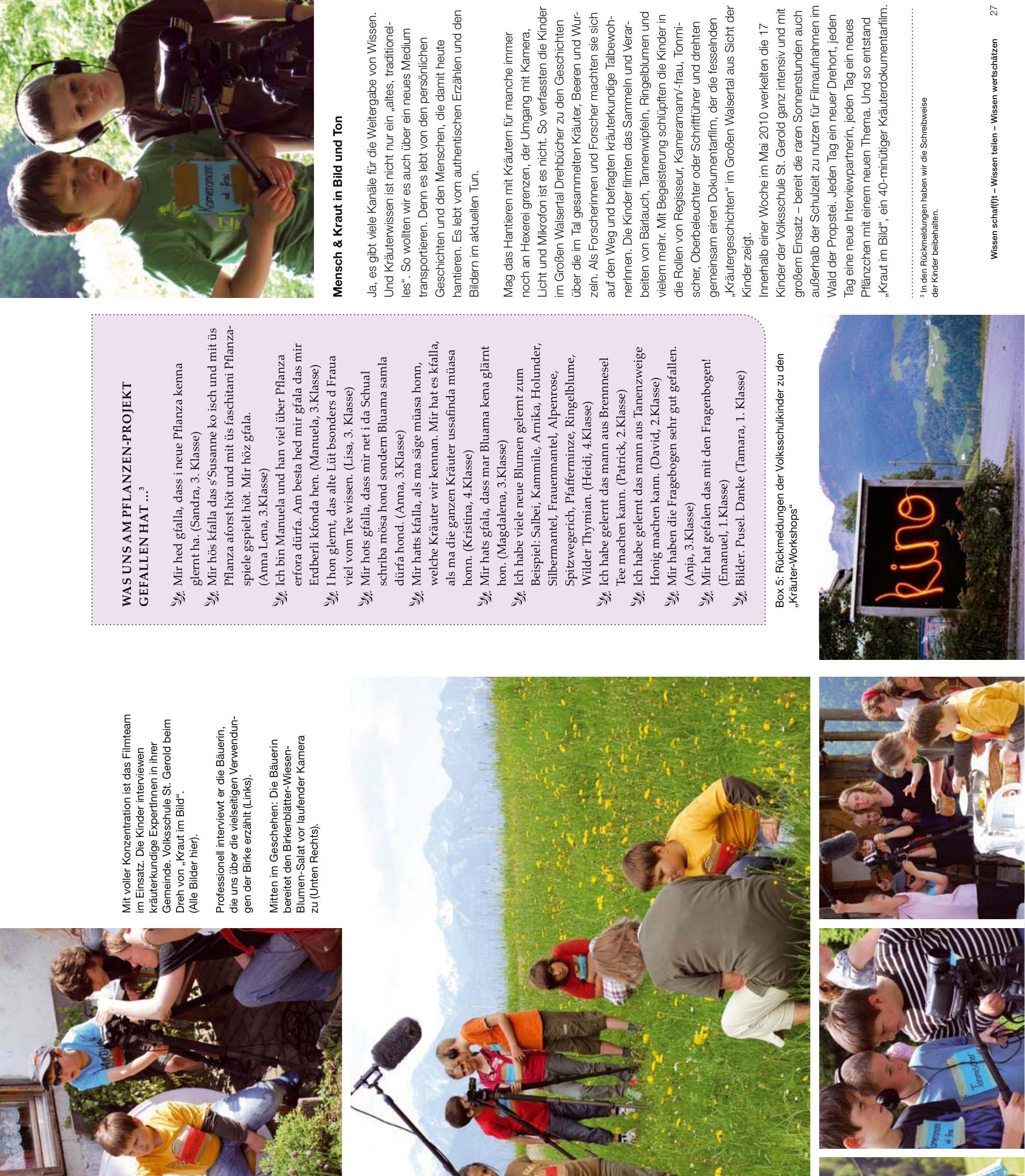

$e^{2}$
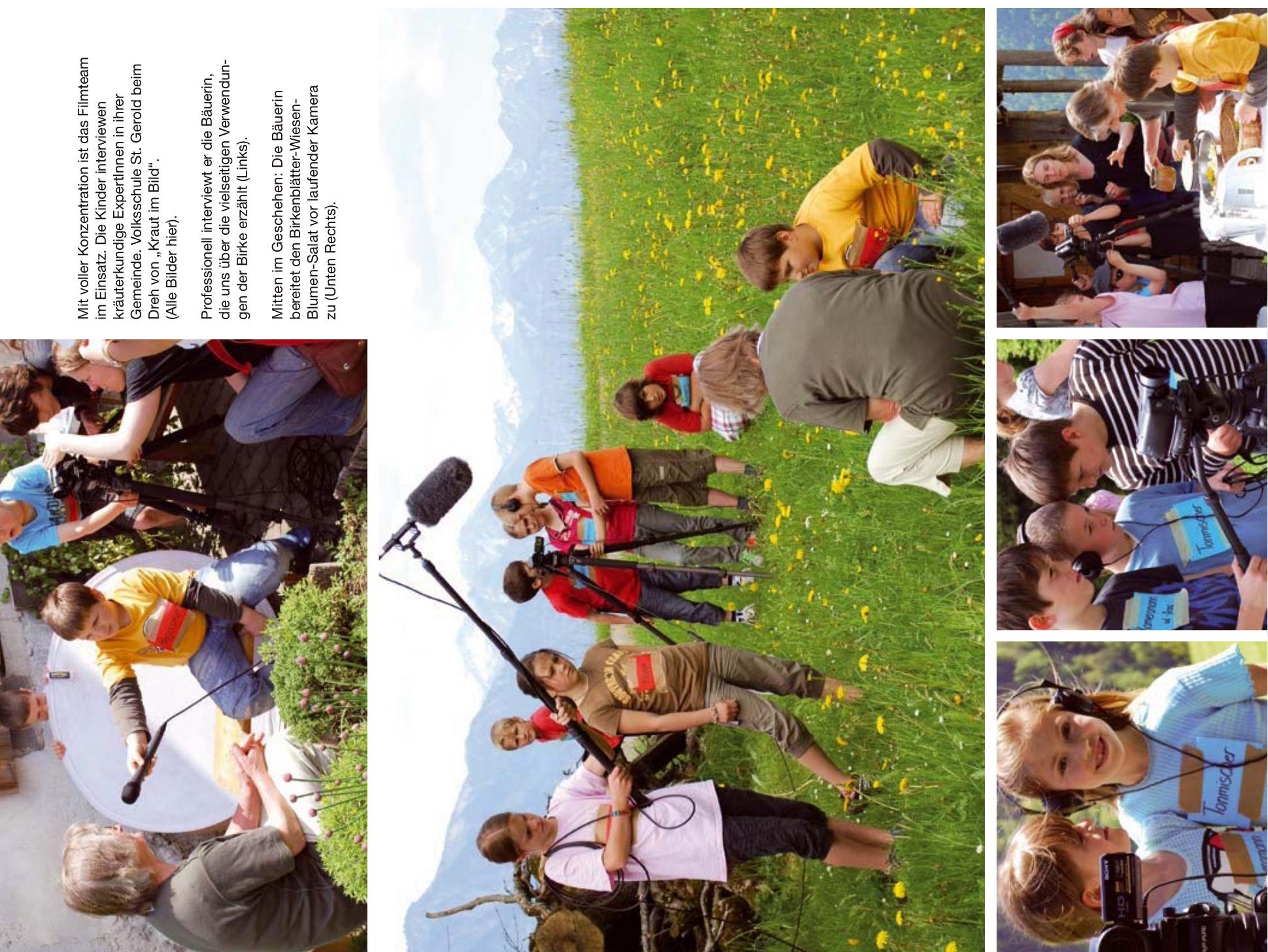


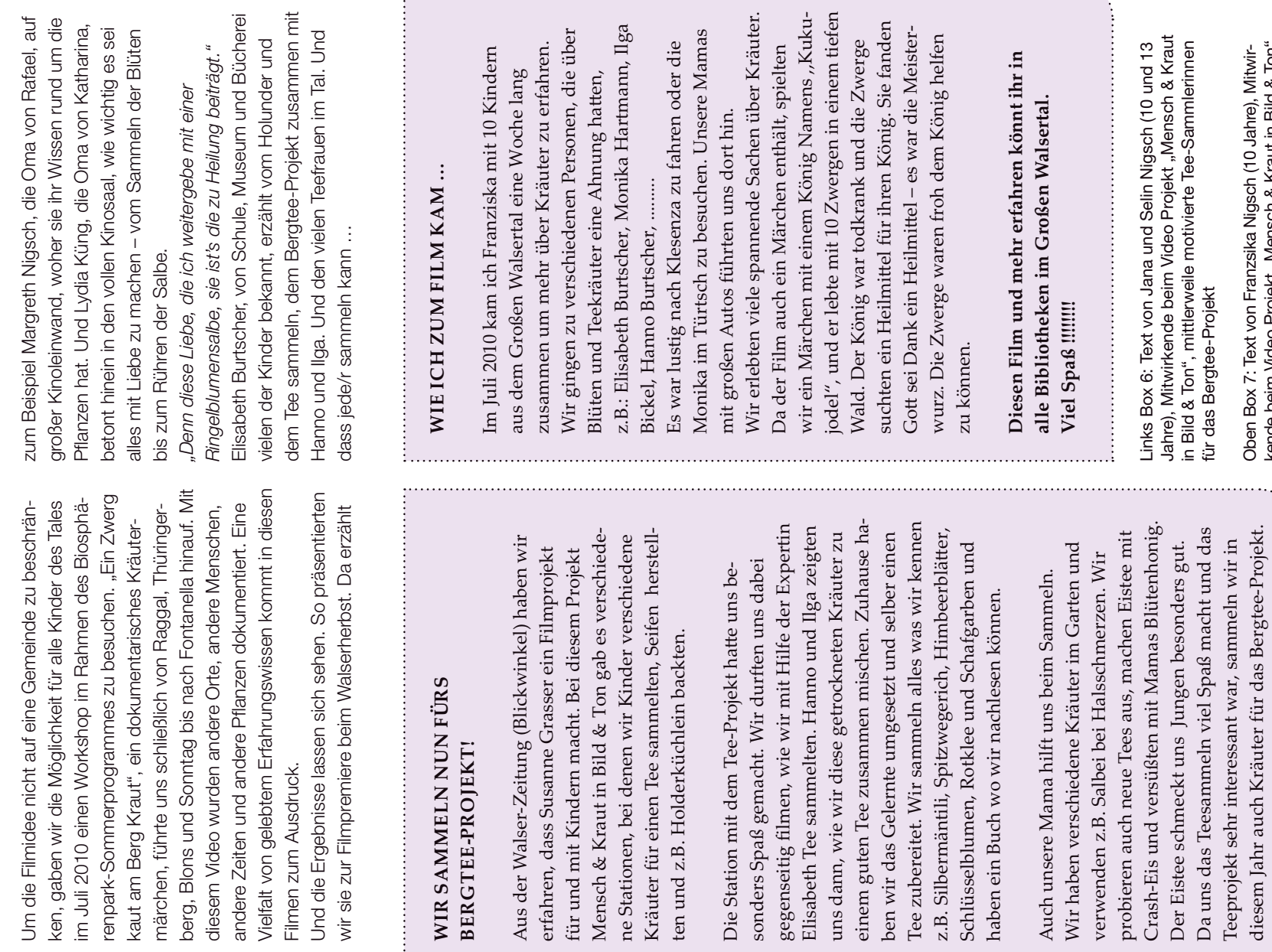

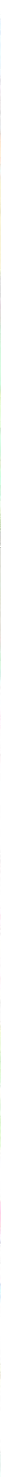




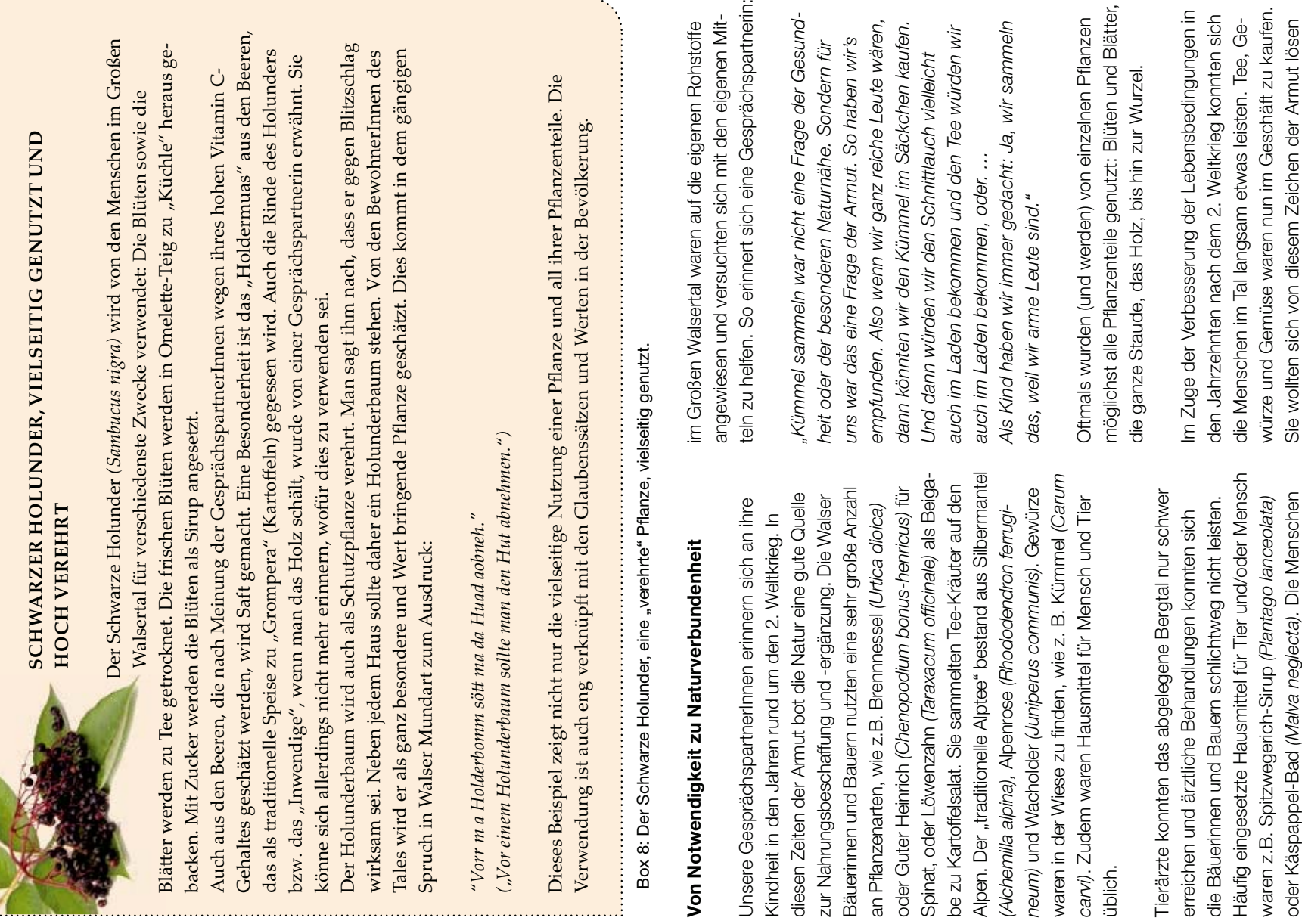

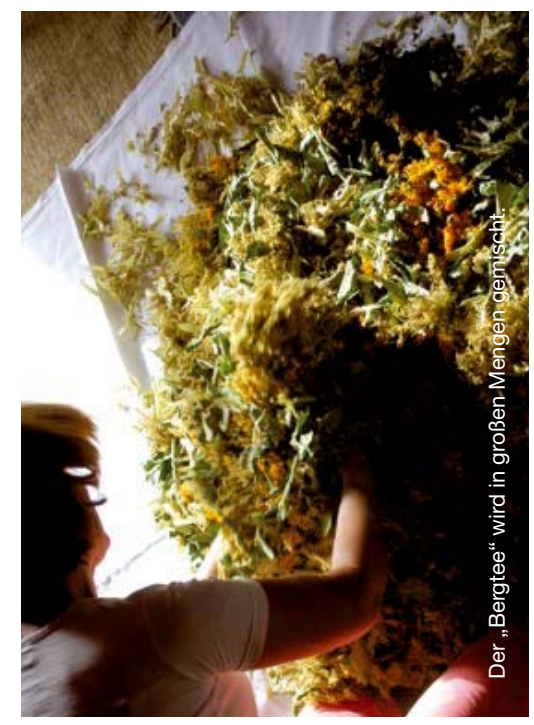
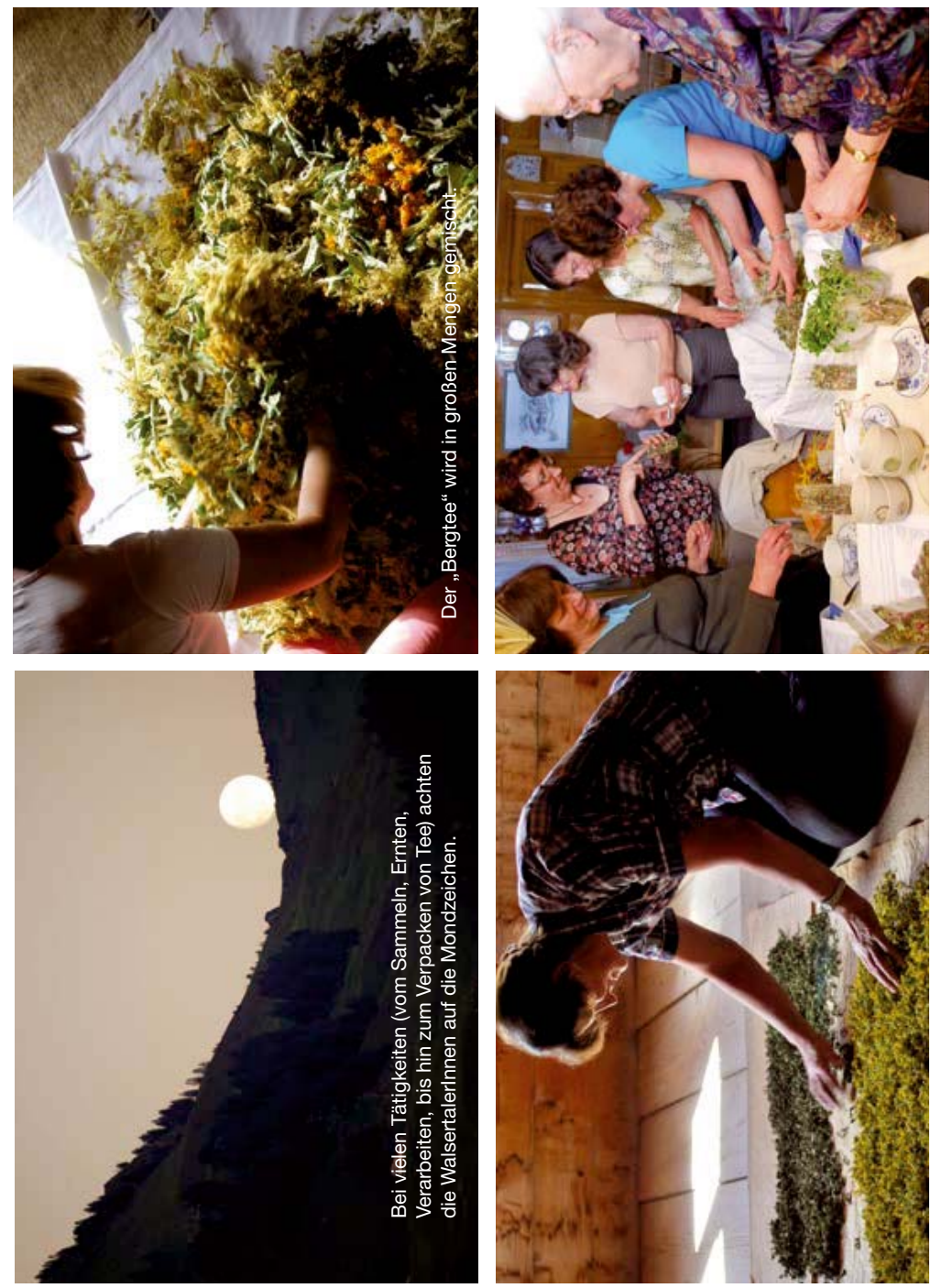

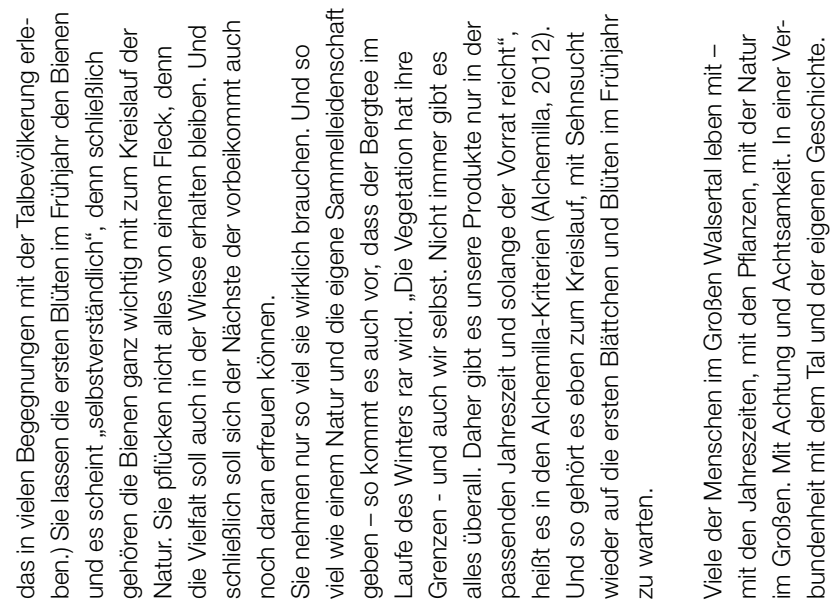

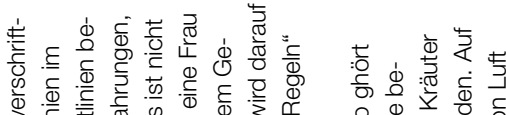

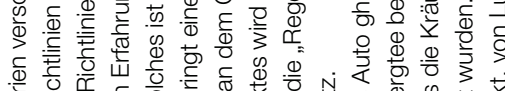

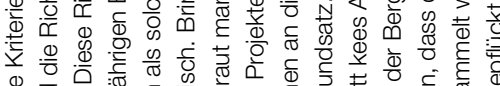

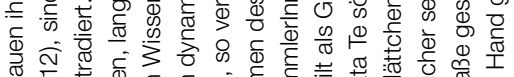

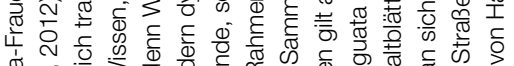

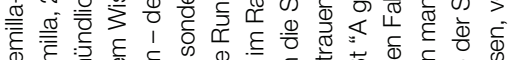

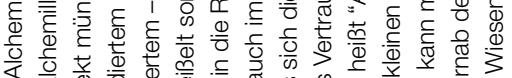

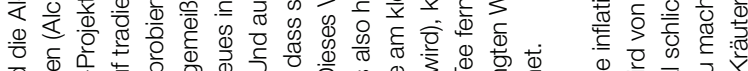

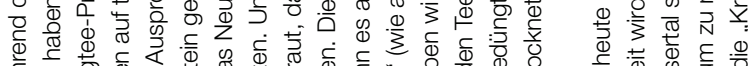

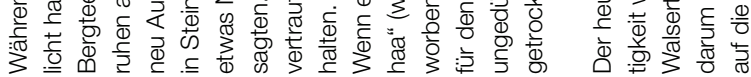


orar.

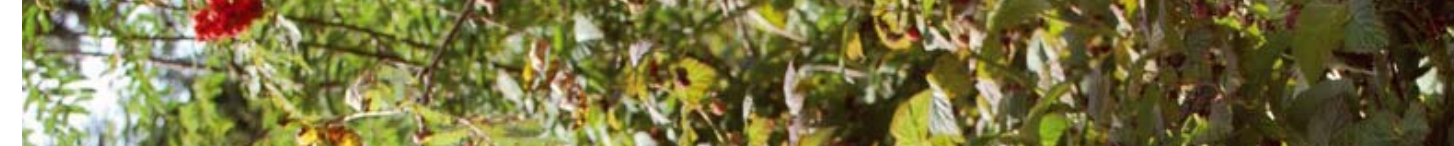

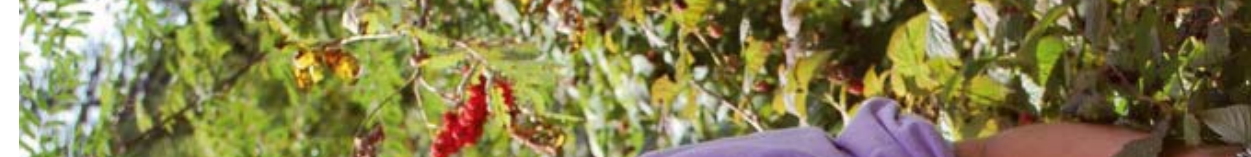

3.

\section{o. al the is?}

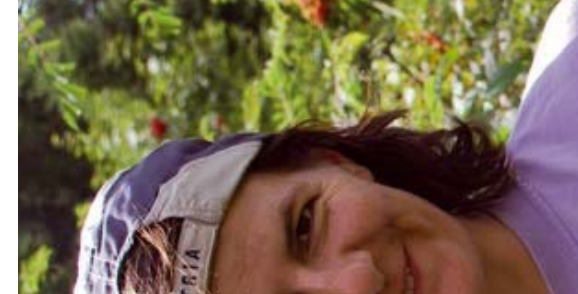

\section{Q}

(2)

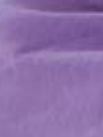

\section{Q8)}

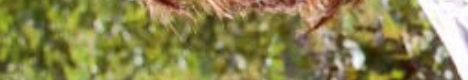

Fon

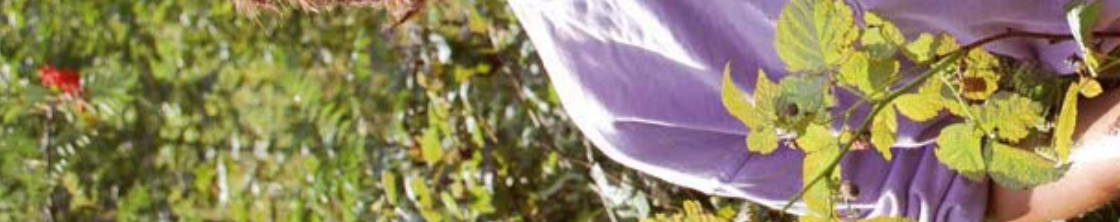

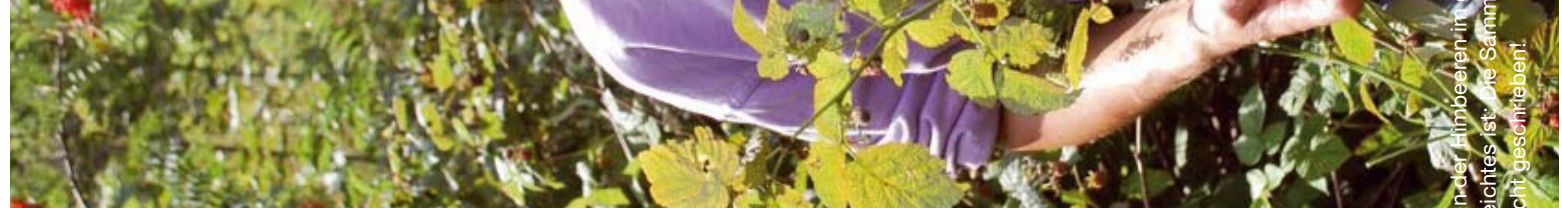

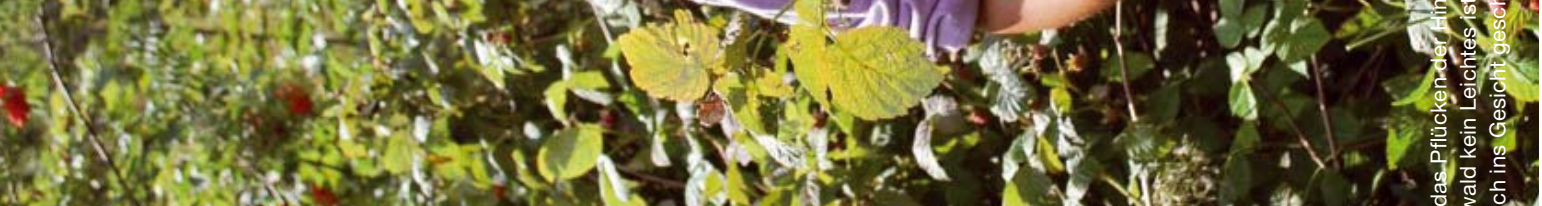
- x r 1 .

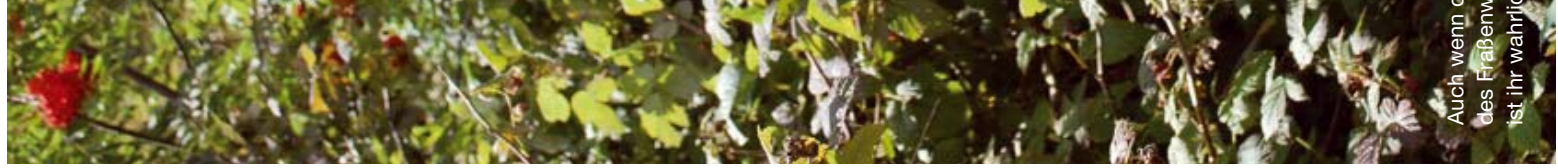
$4 x^{2}$

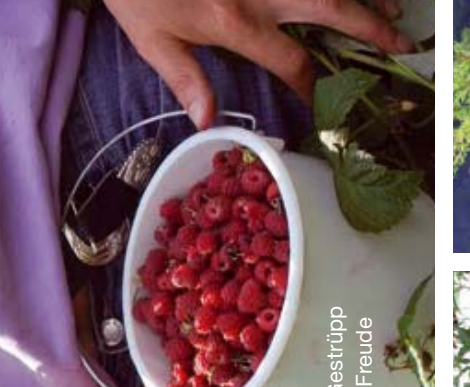

e)
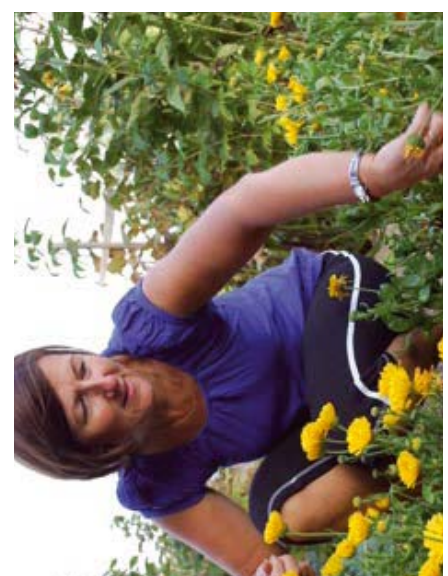
$\sum_{i \rightarrow \infty}$ (x) 10

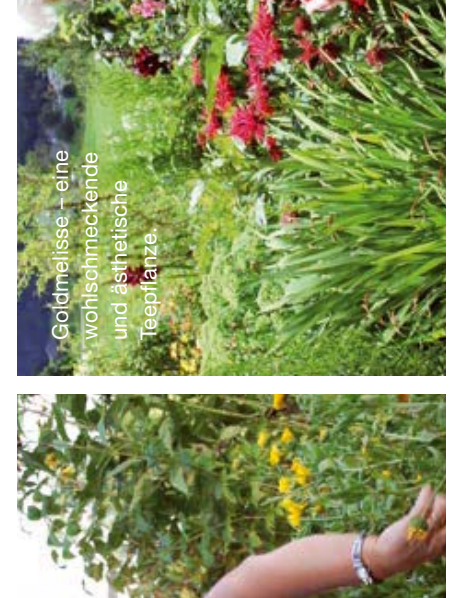

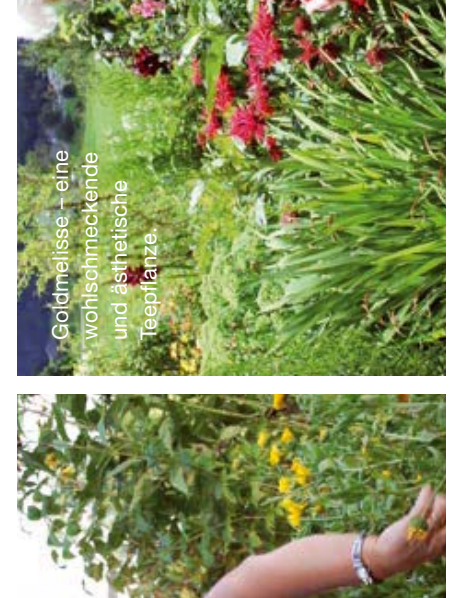

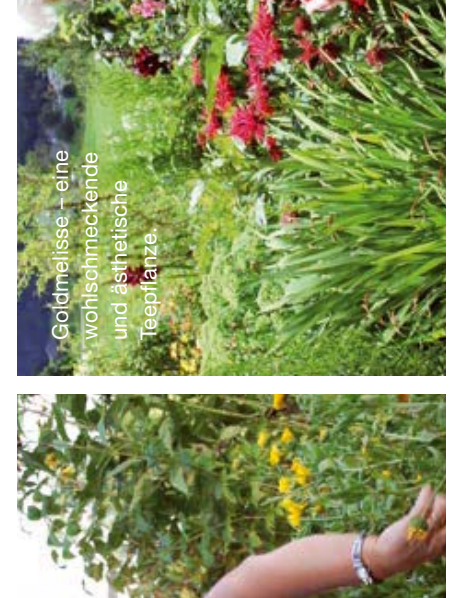

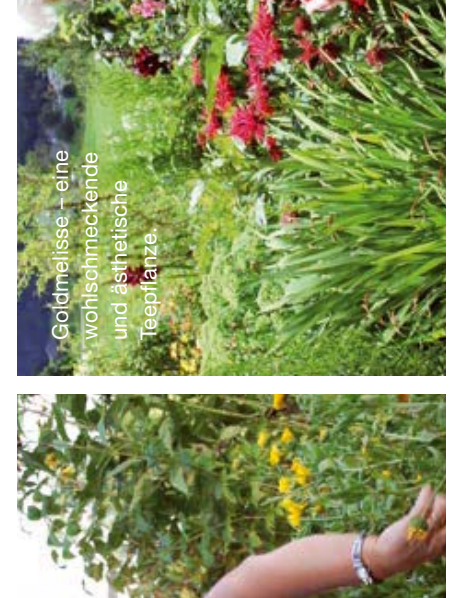

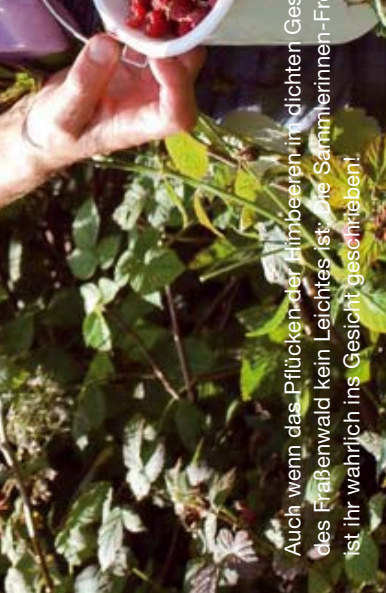
की

(4)

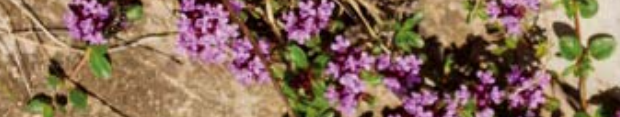
- if $x^{2}+x^{2}+y^{2}$

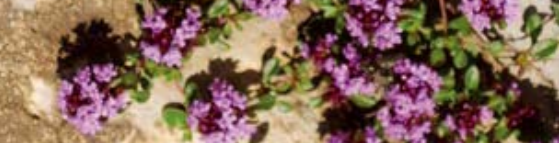

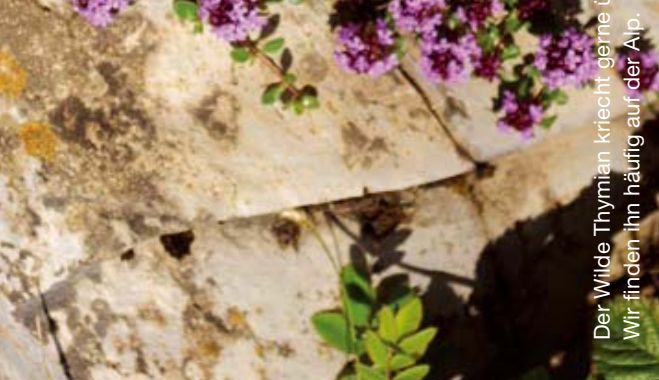
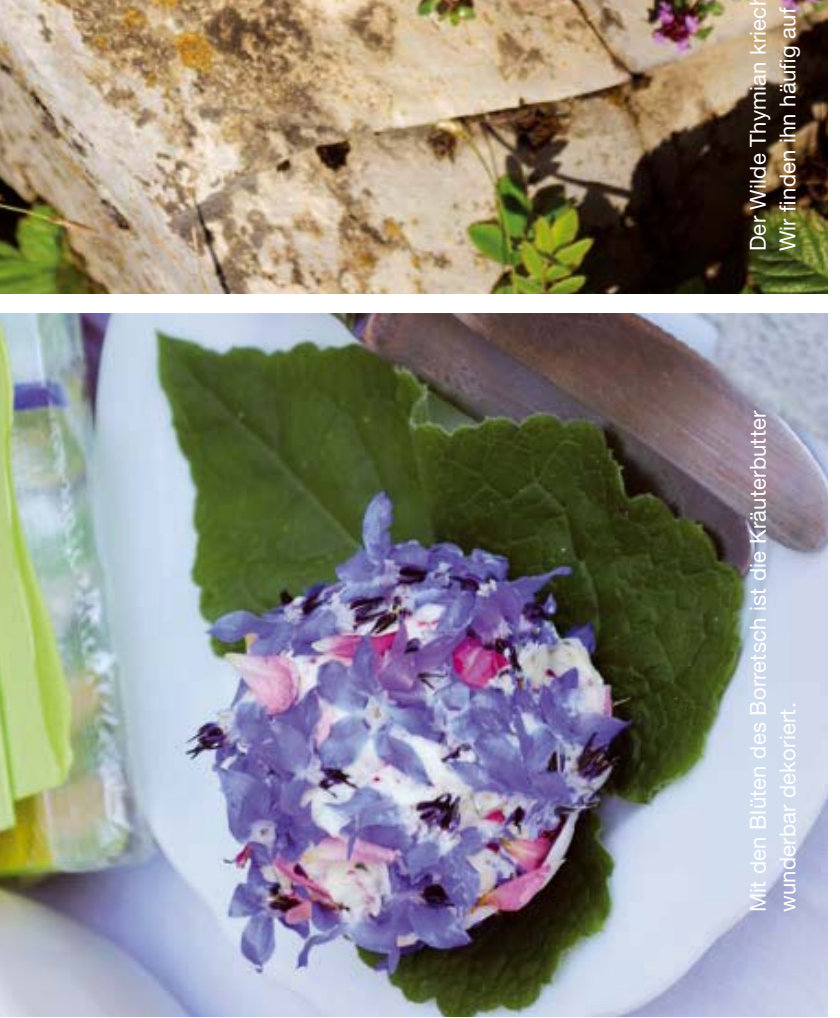

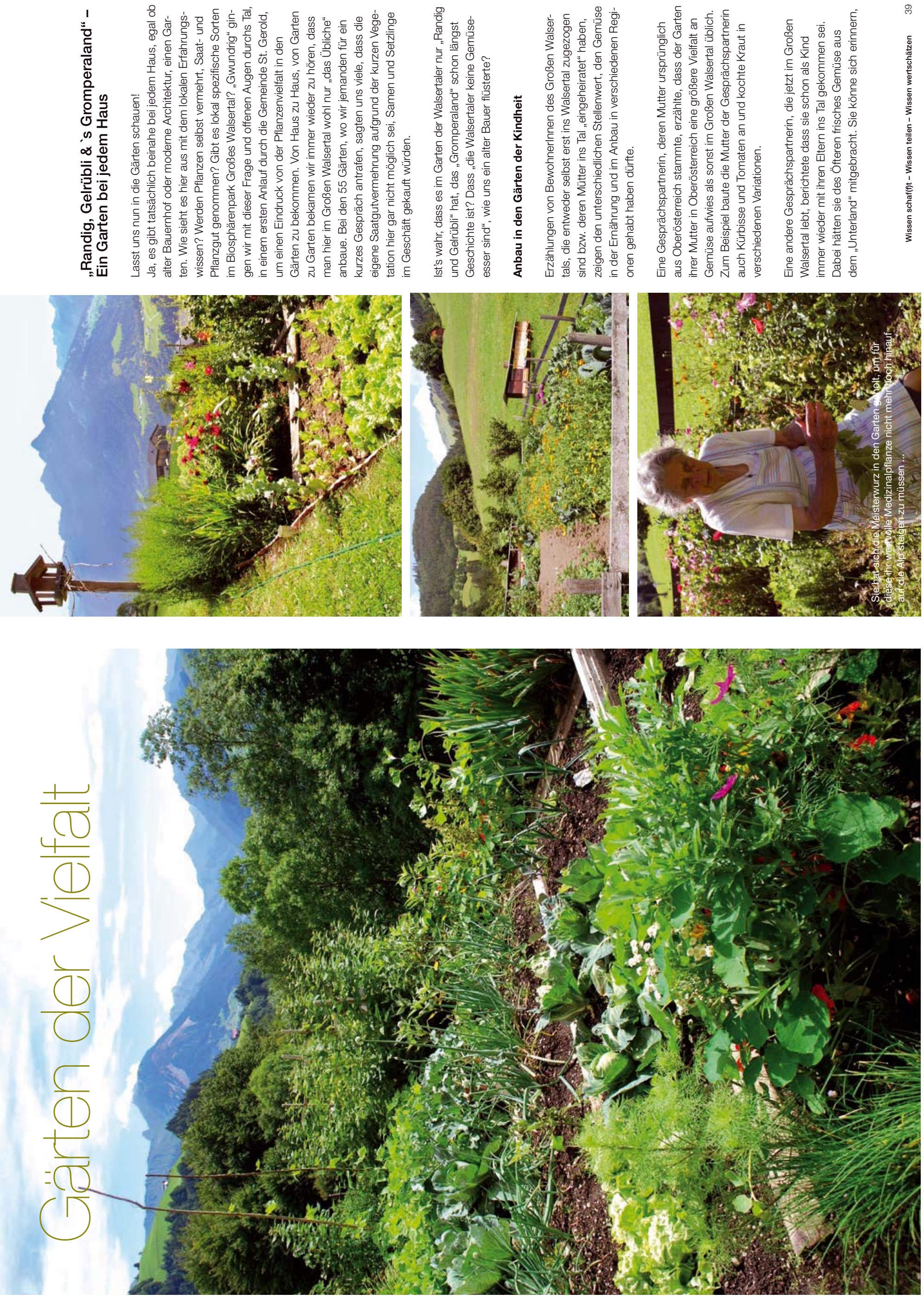

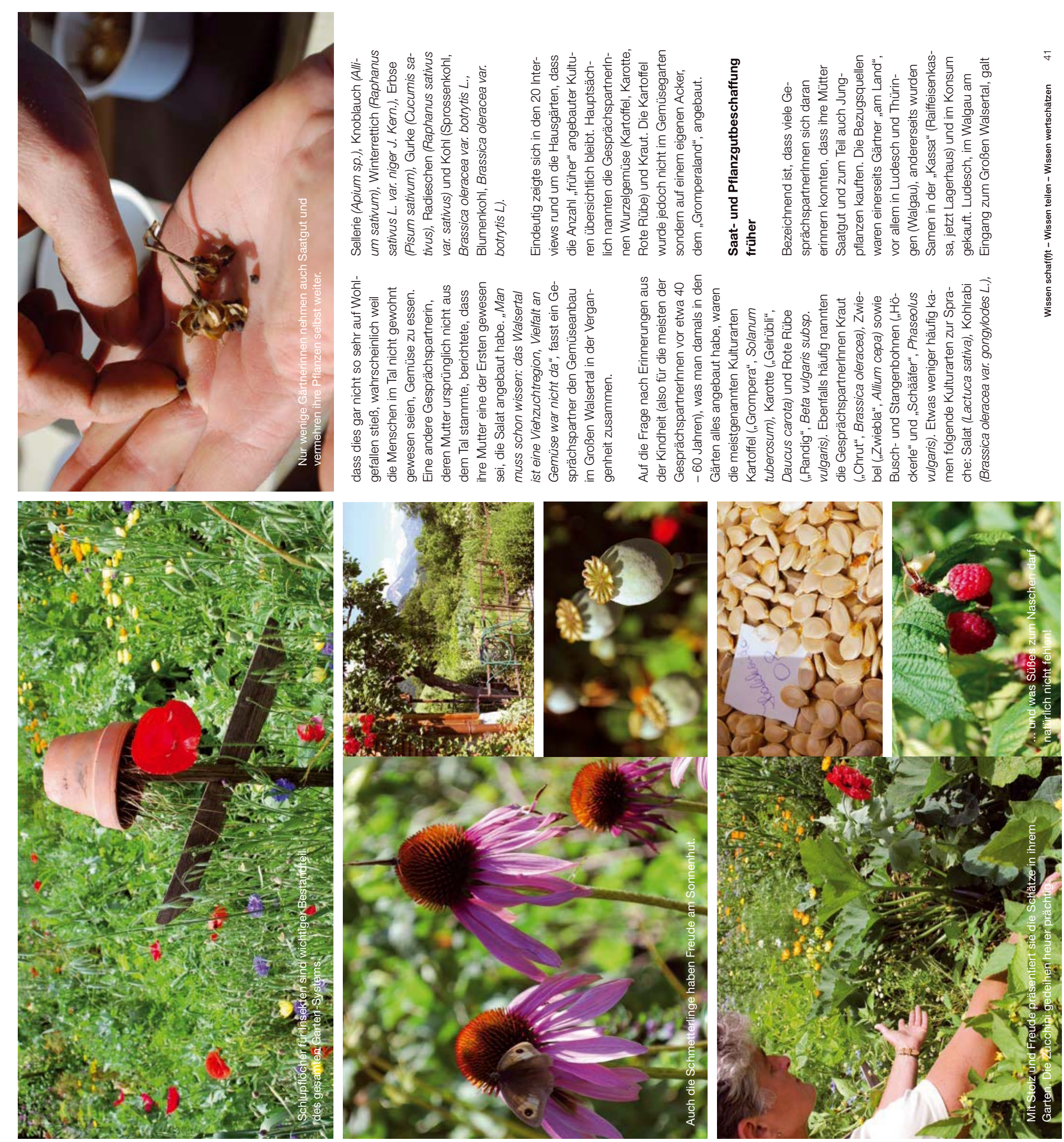

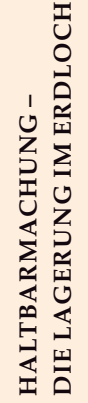

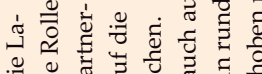
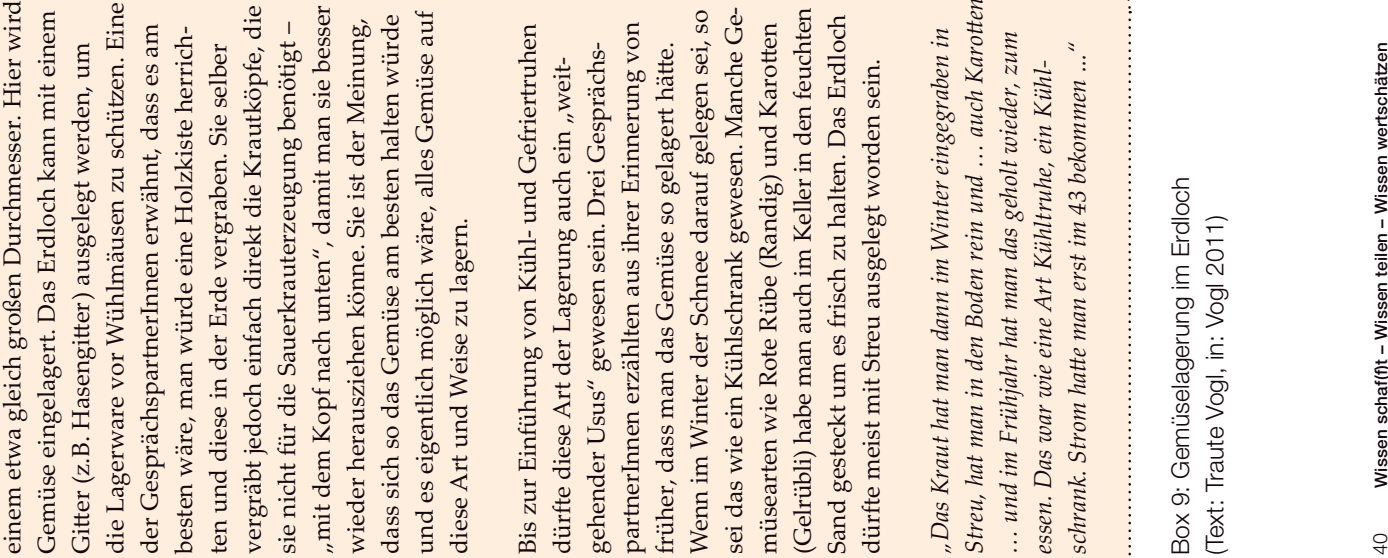


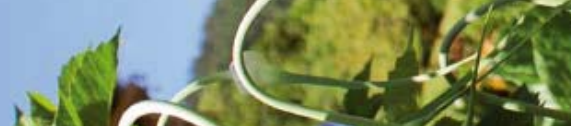
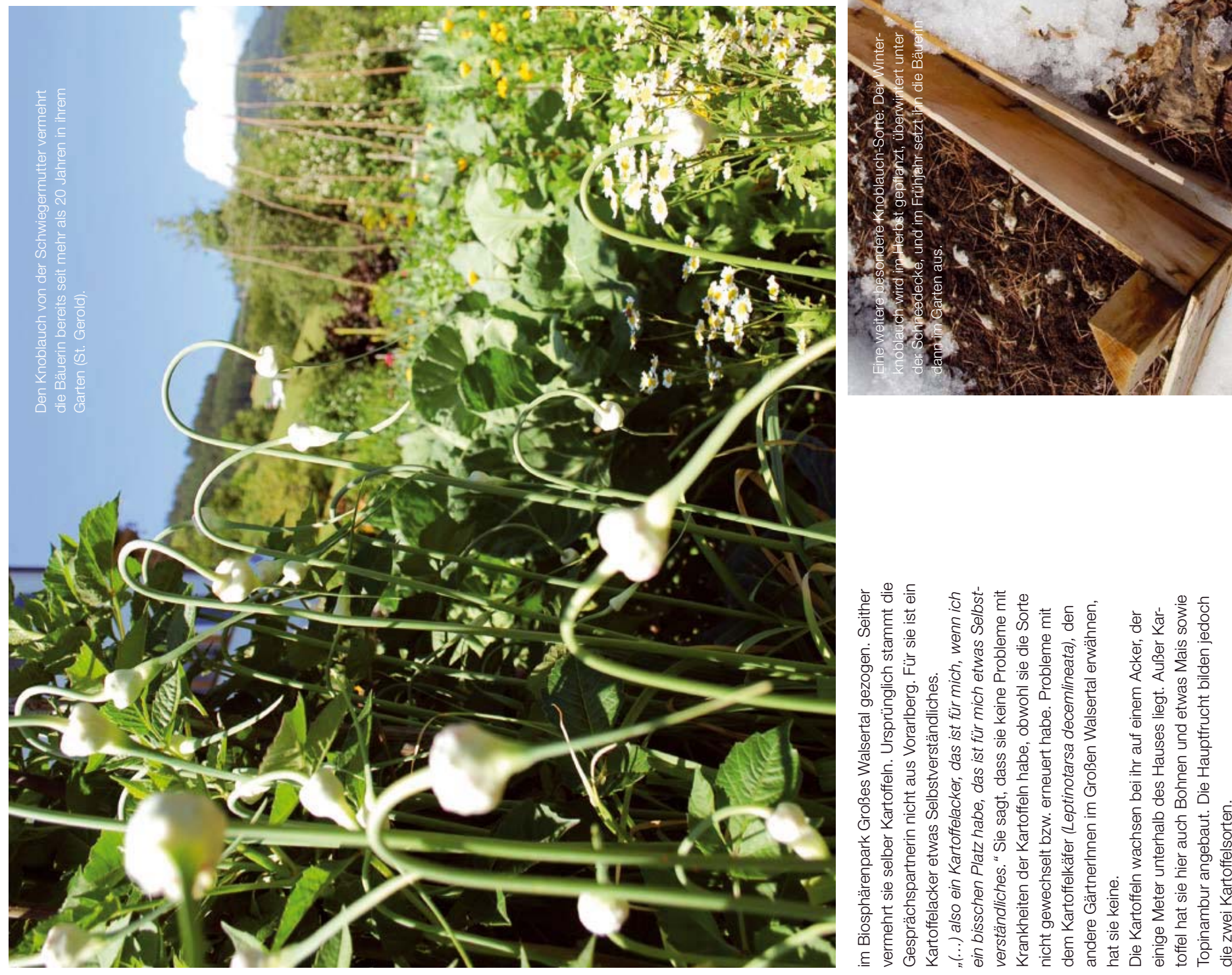

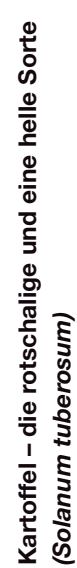
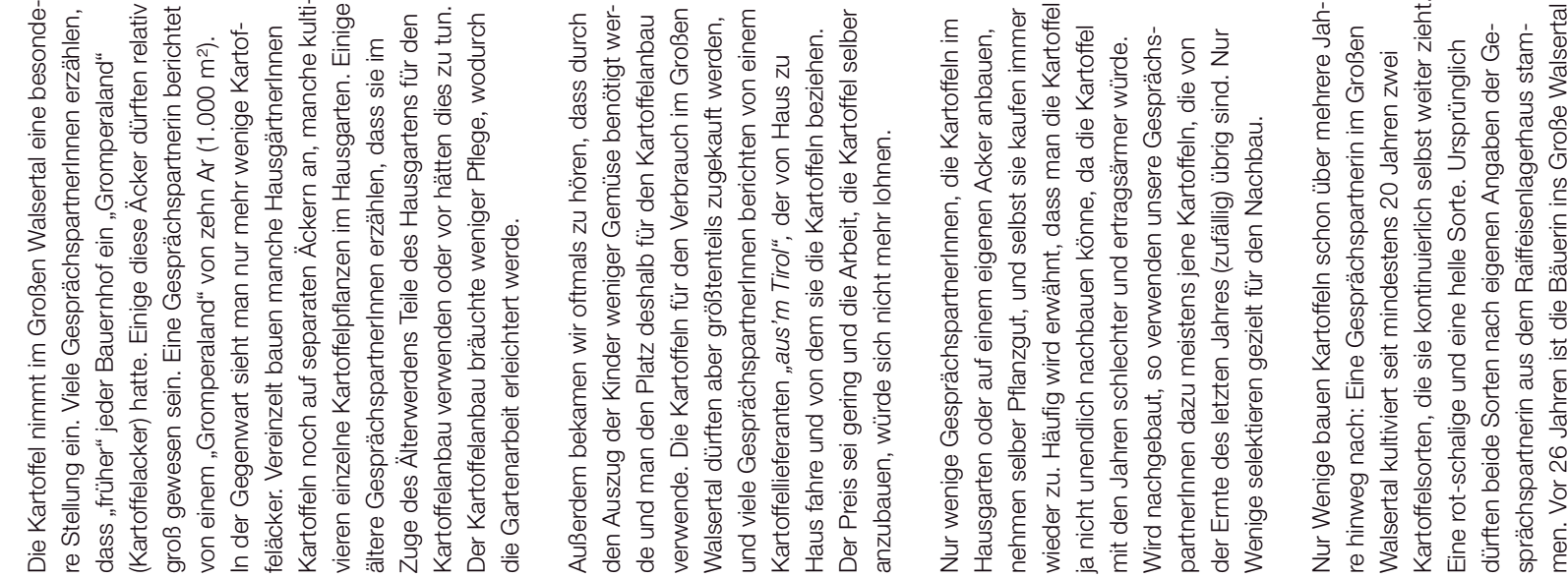

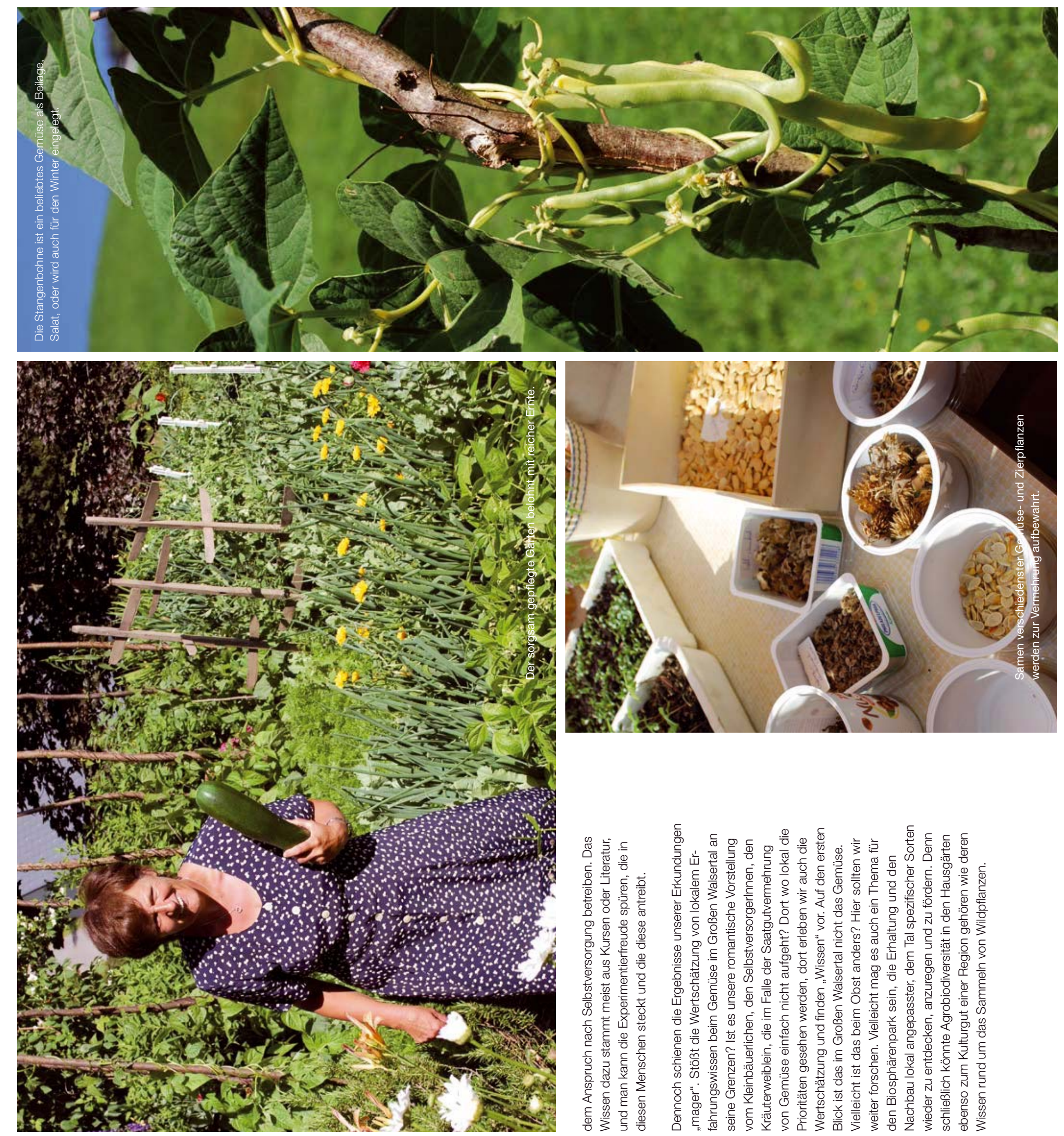

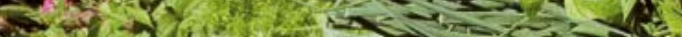
if 2.

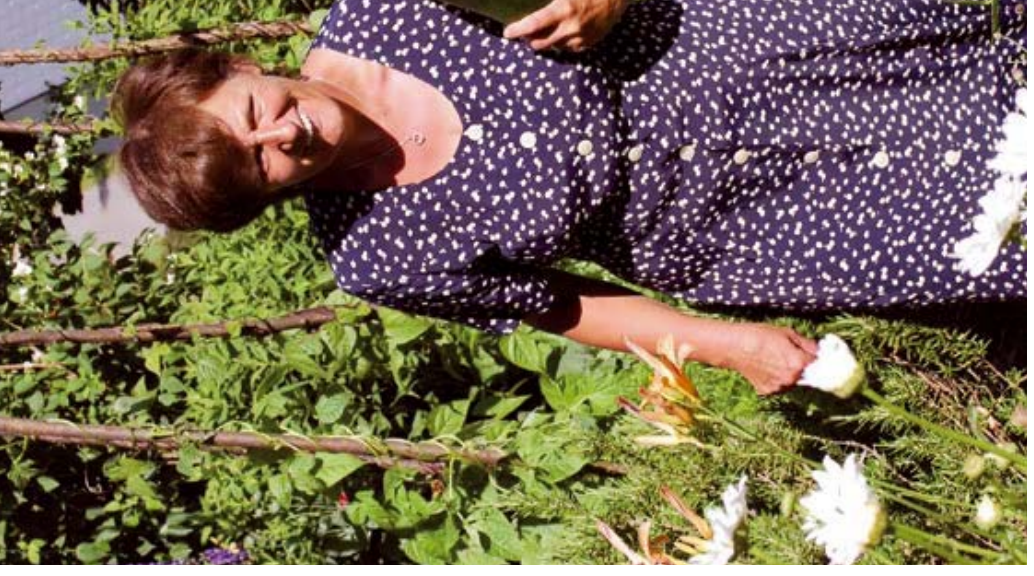

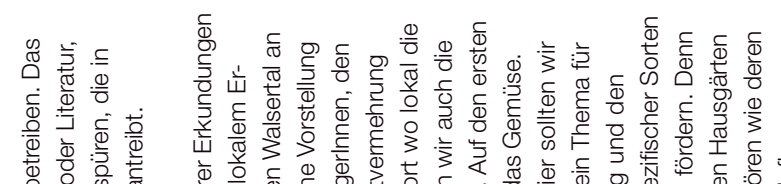




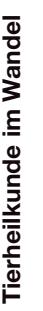

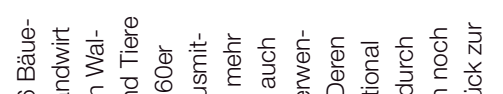

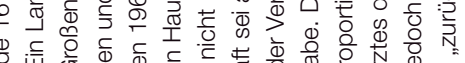

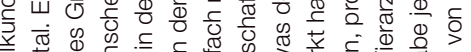

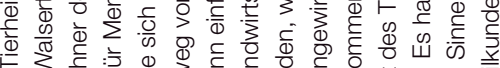

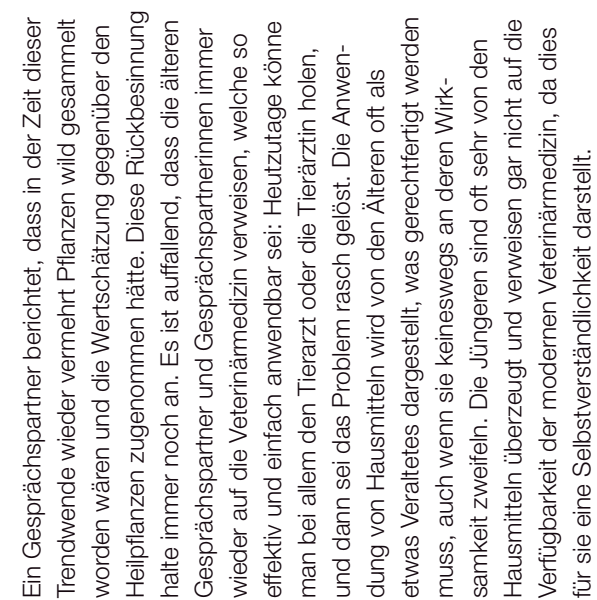

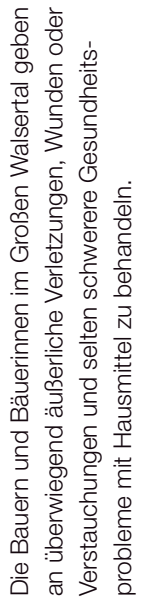

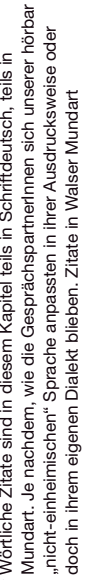

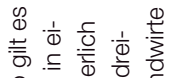

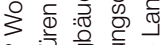

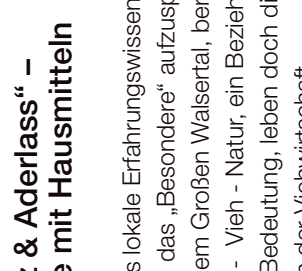

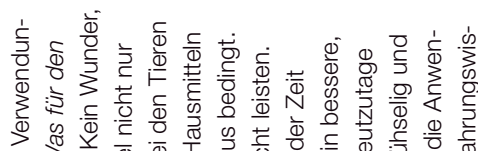

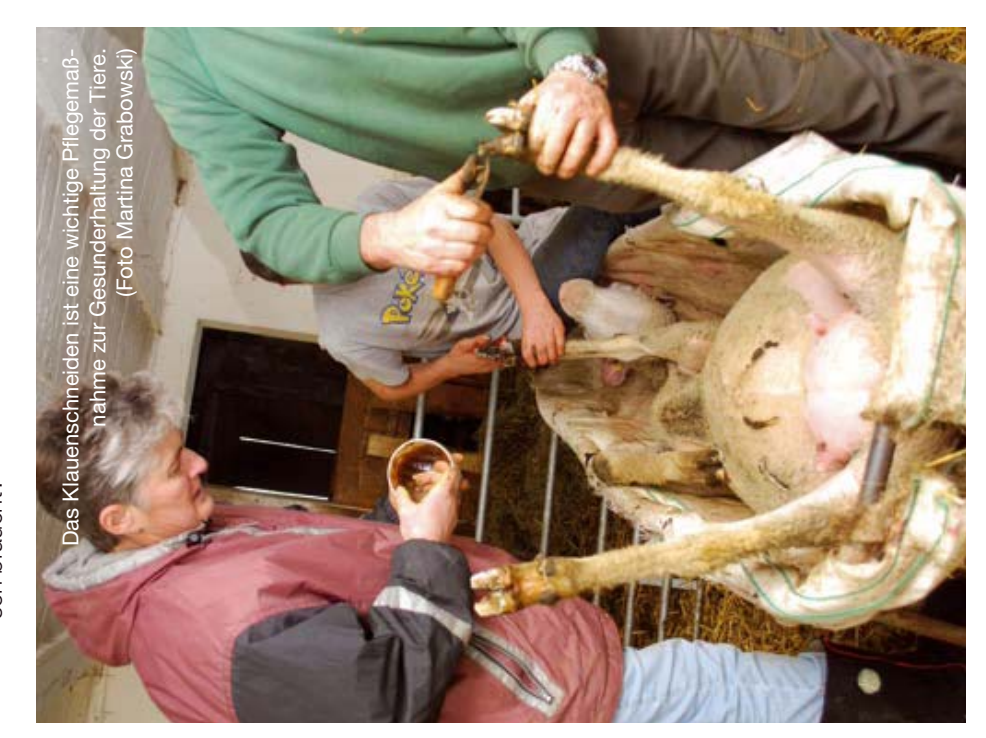

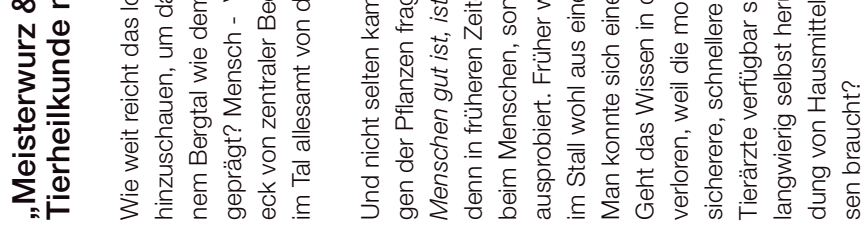
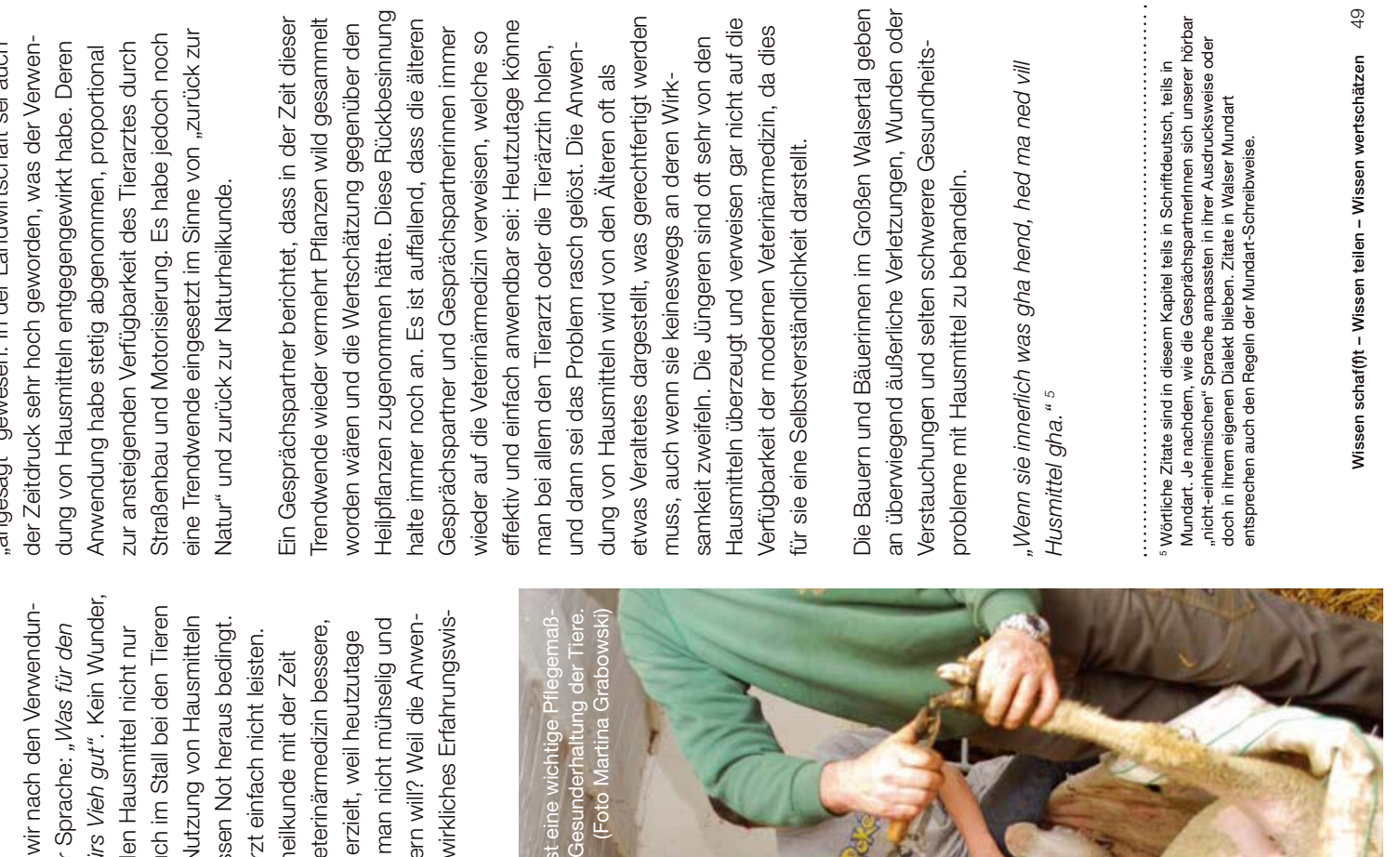

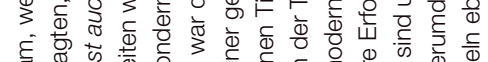
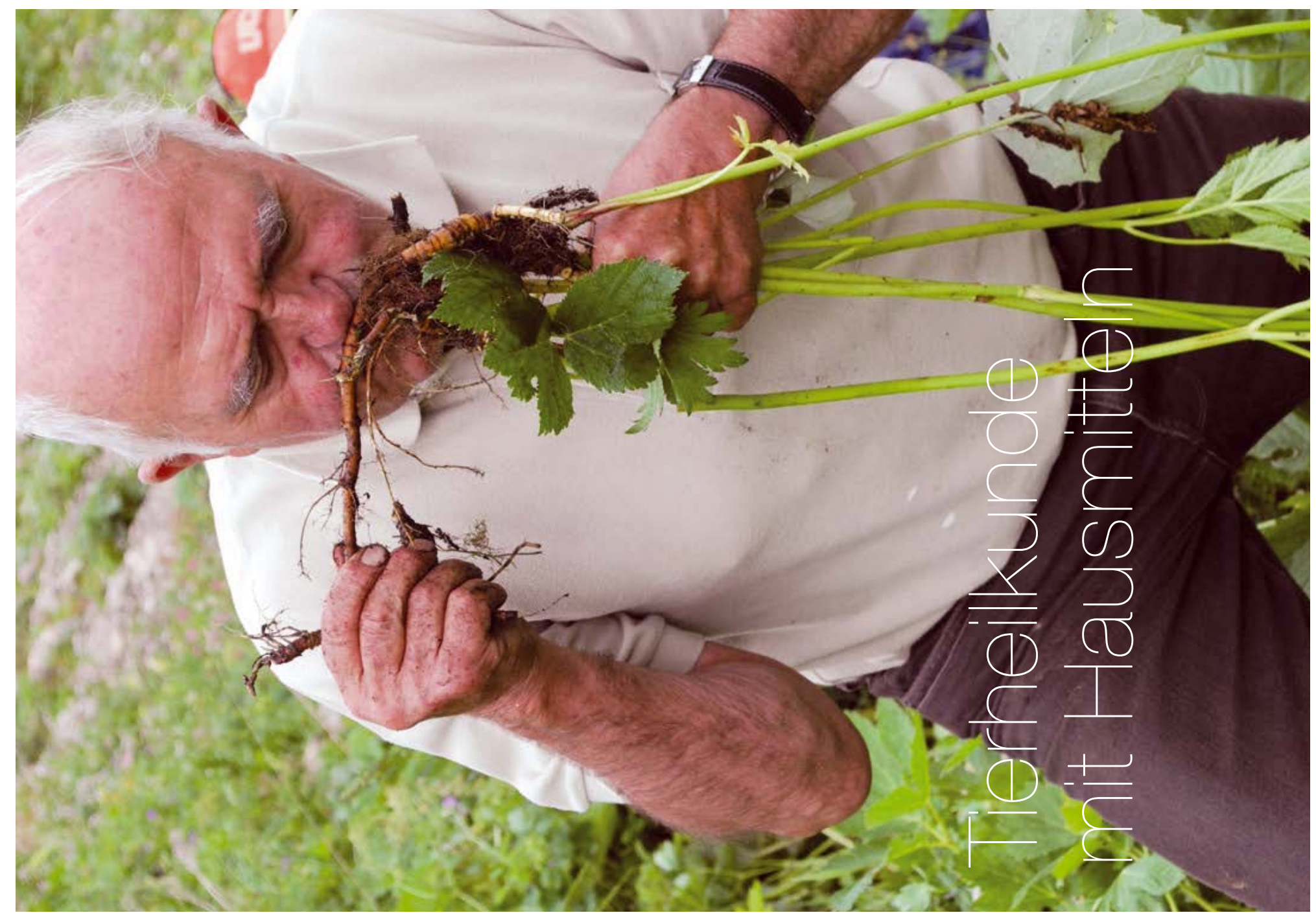

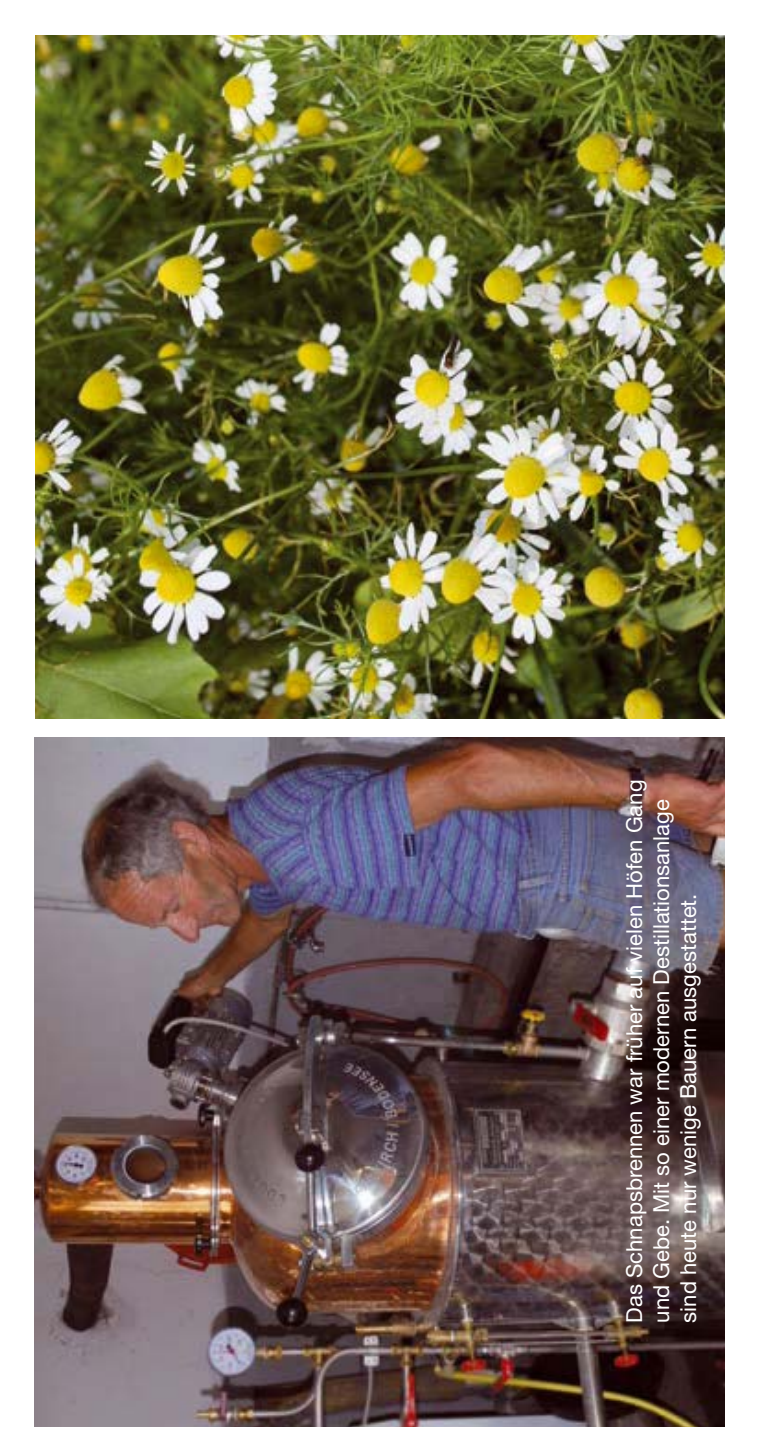

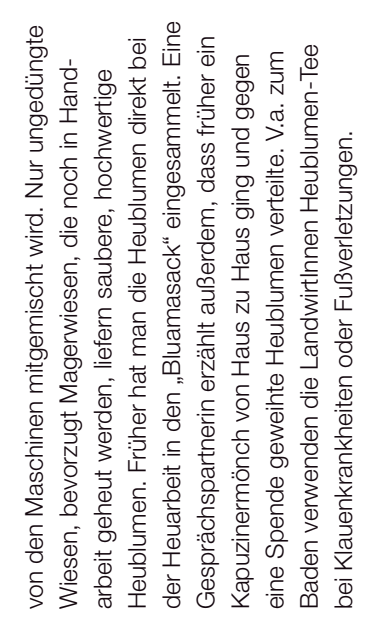

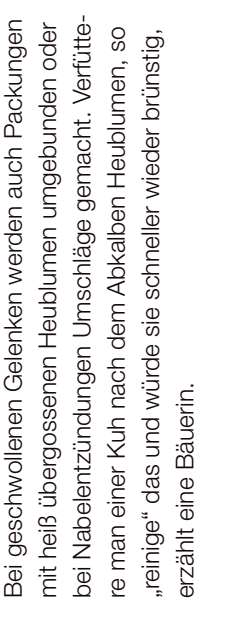

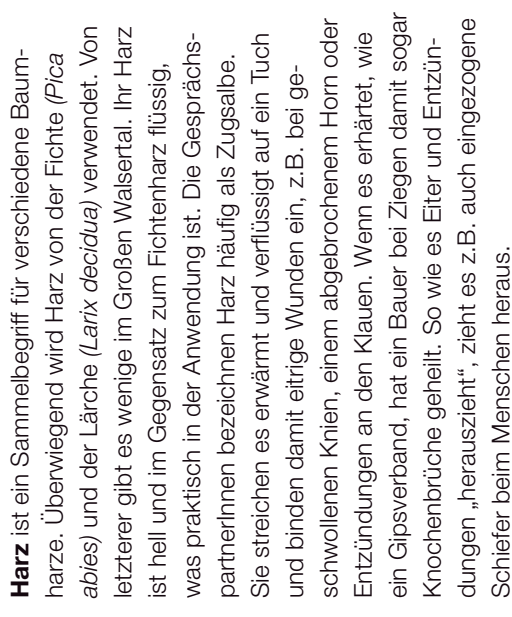

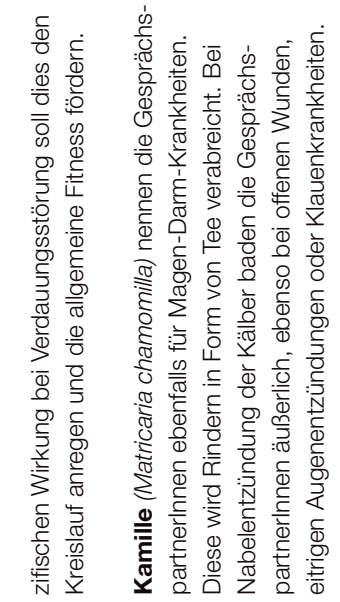
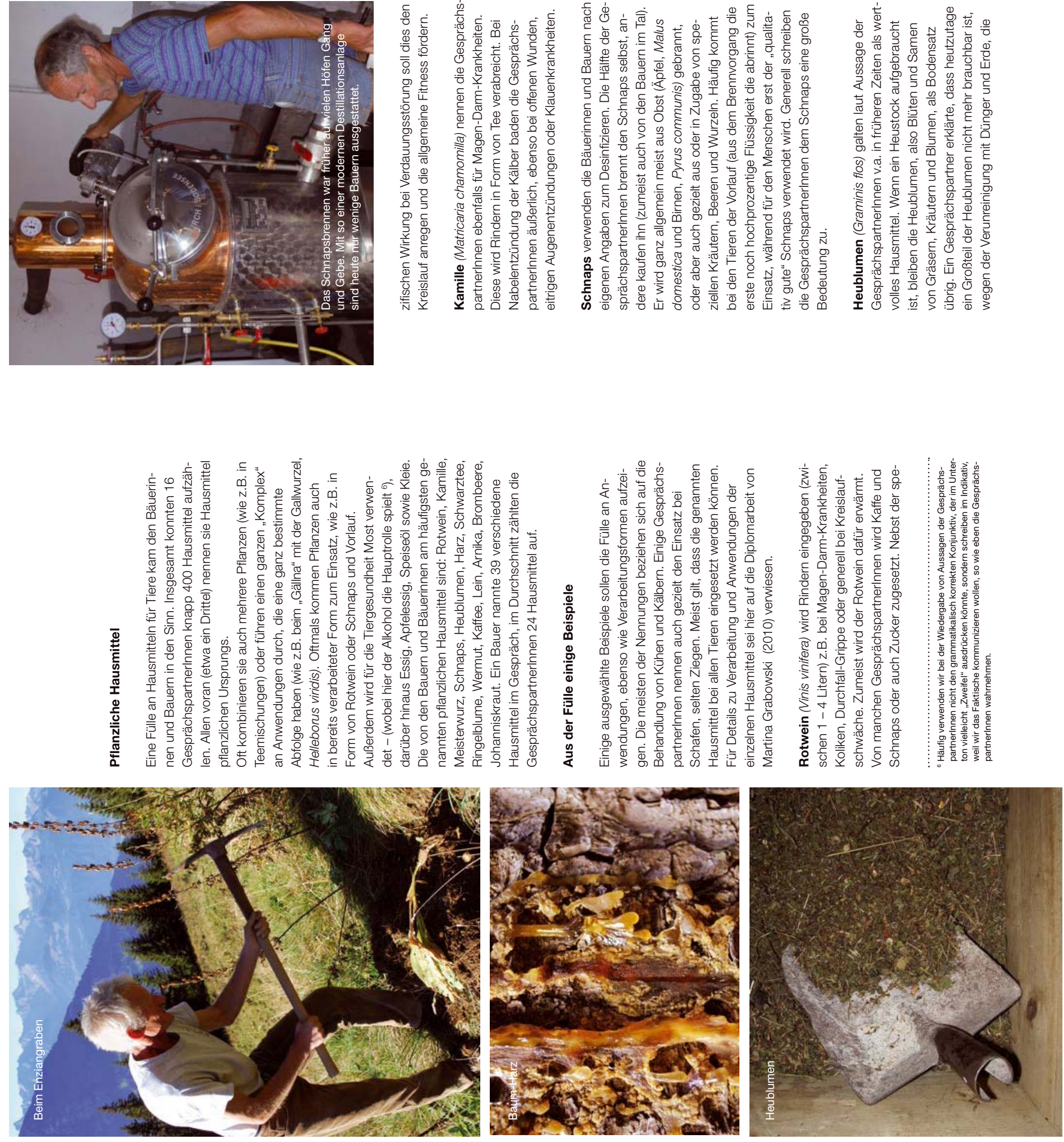

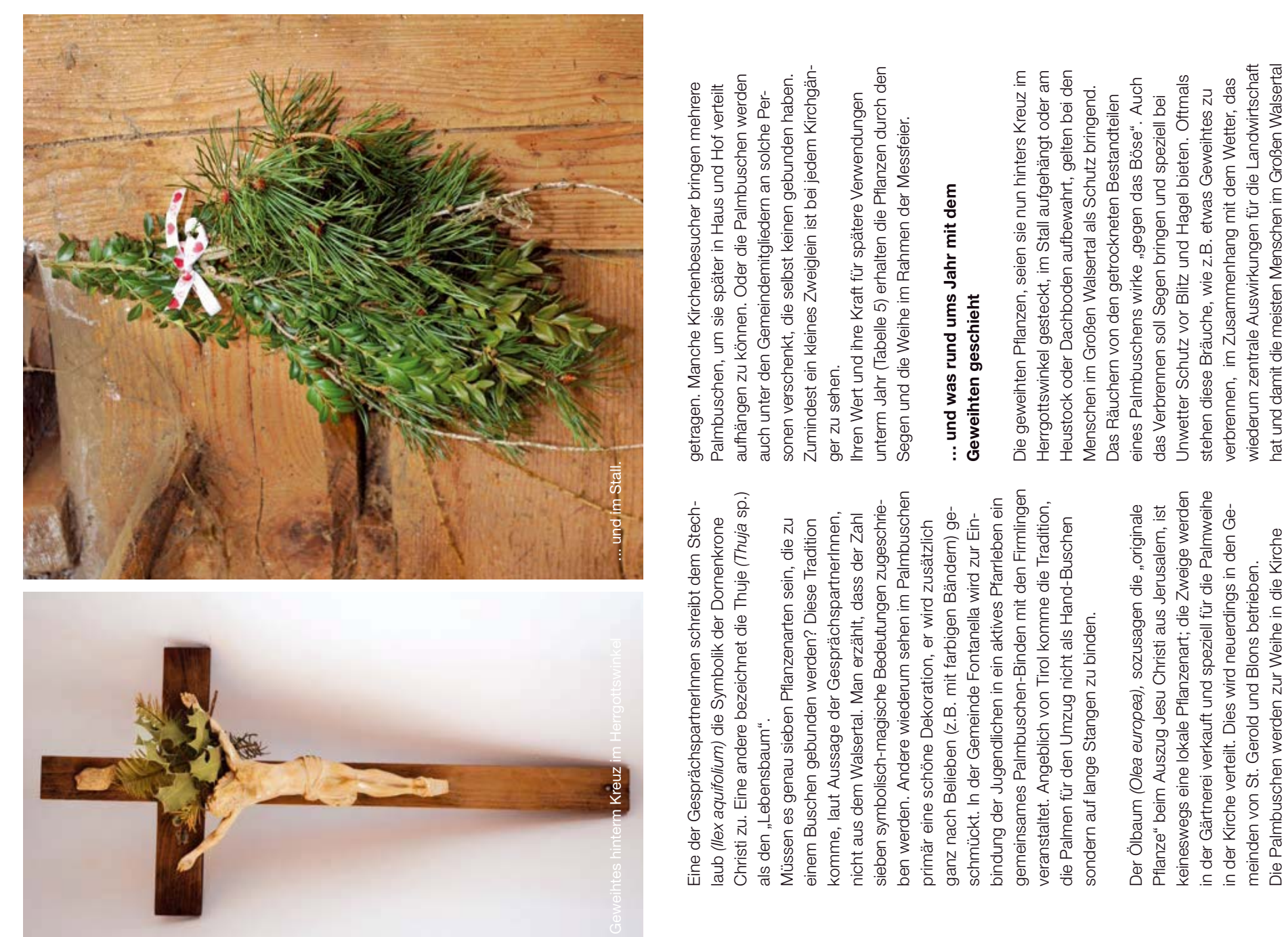

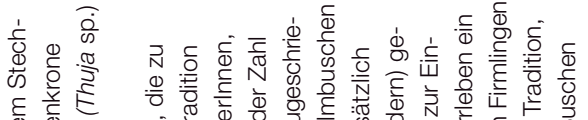

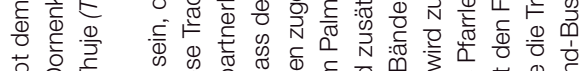

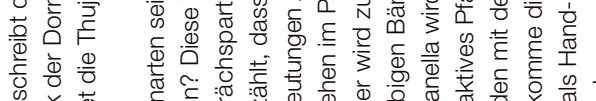

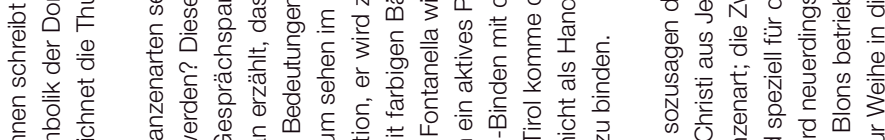

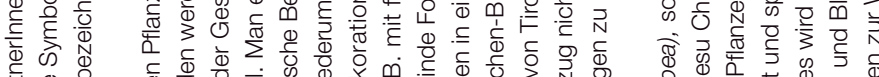

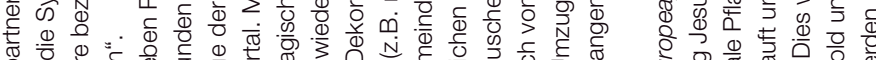

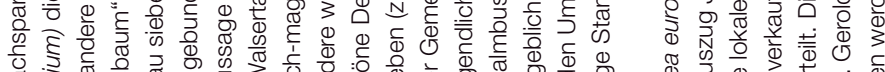

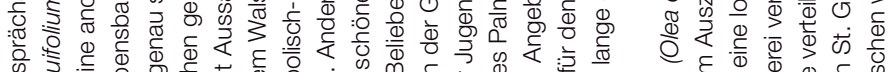

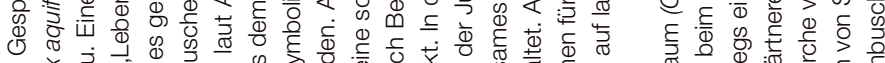

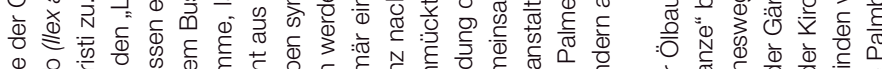

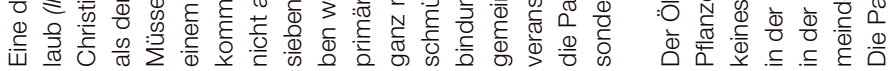
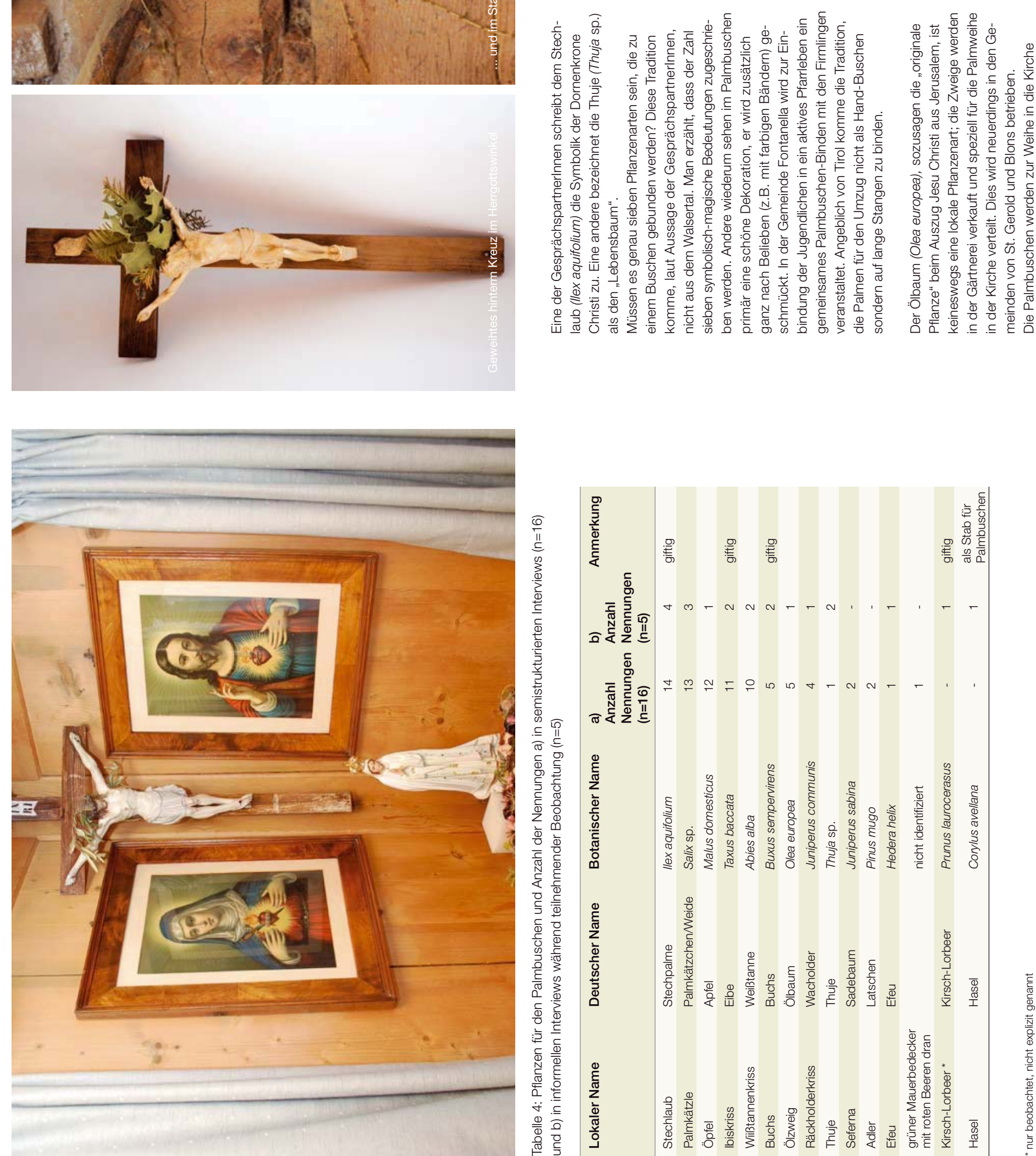


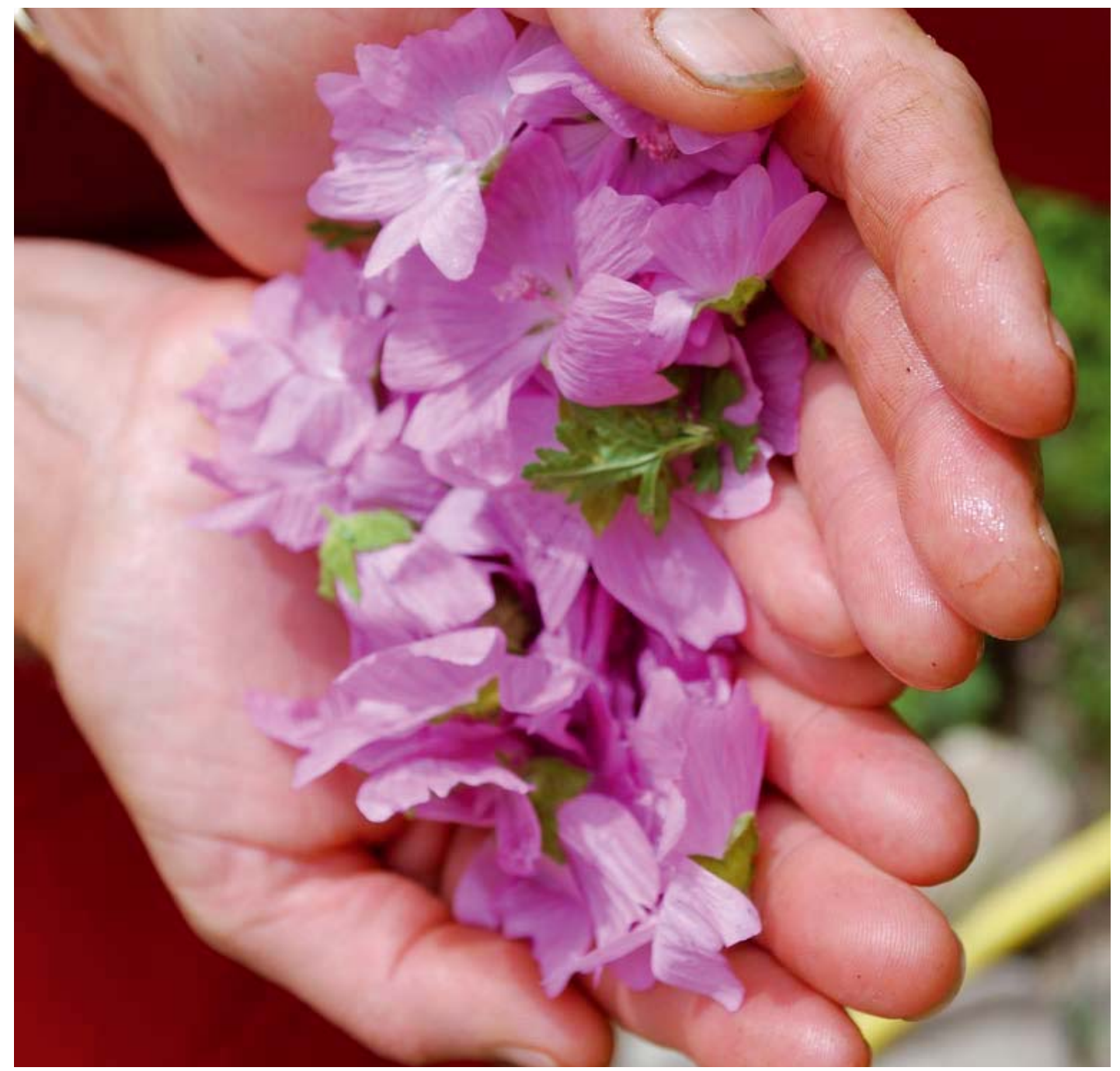

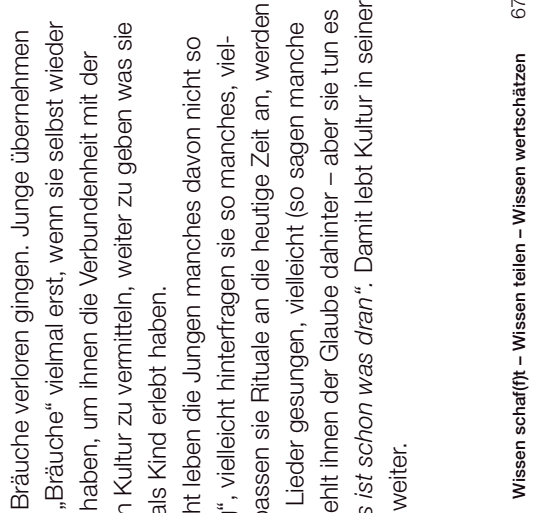

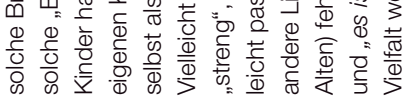
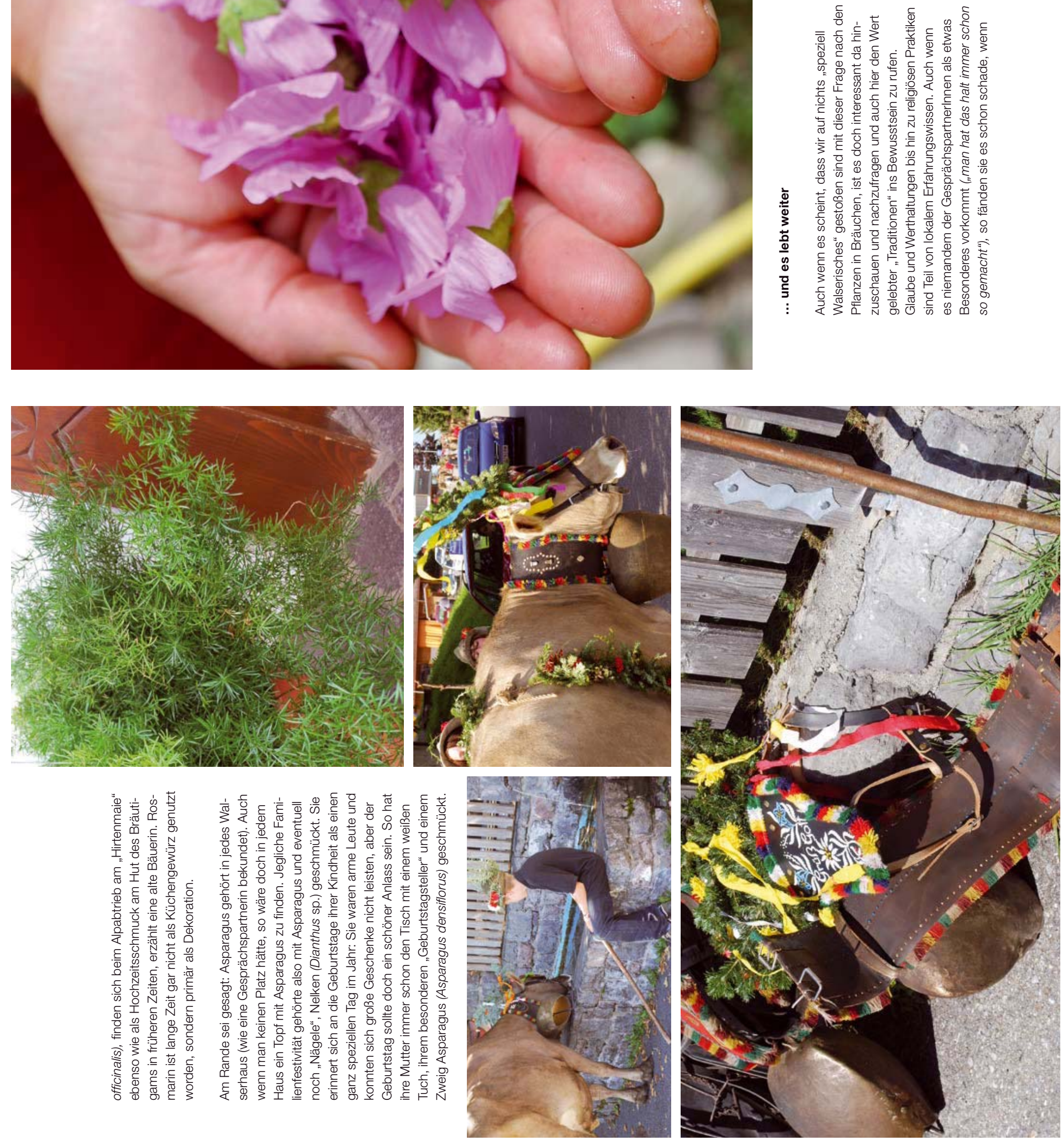


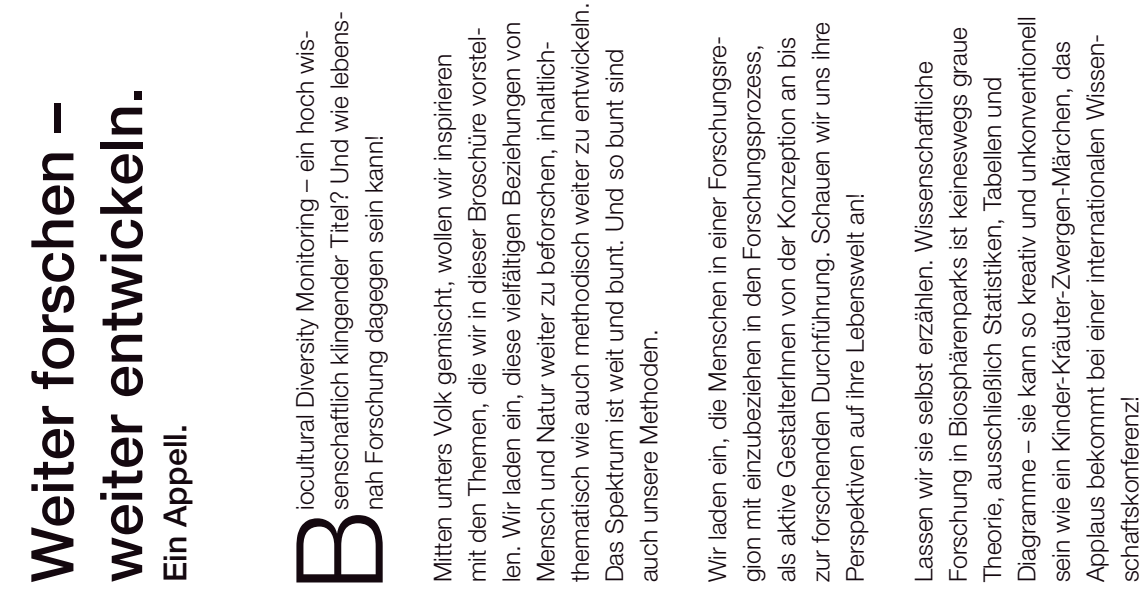

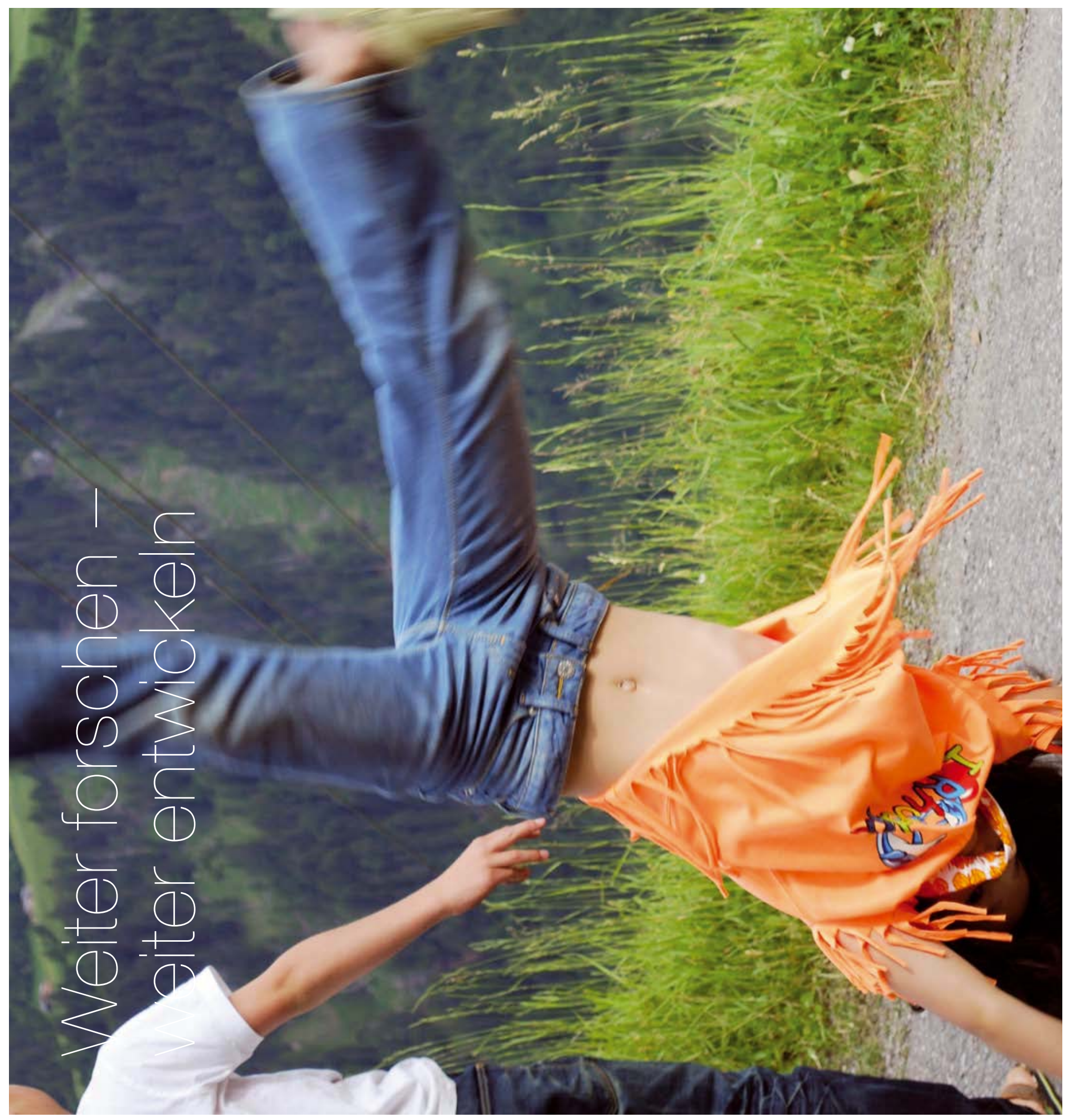



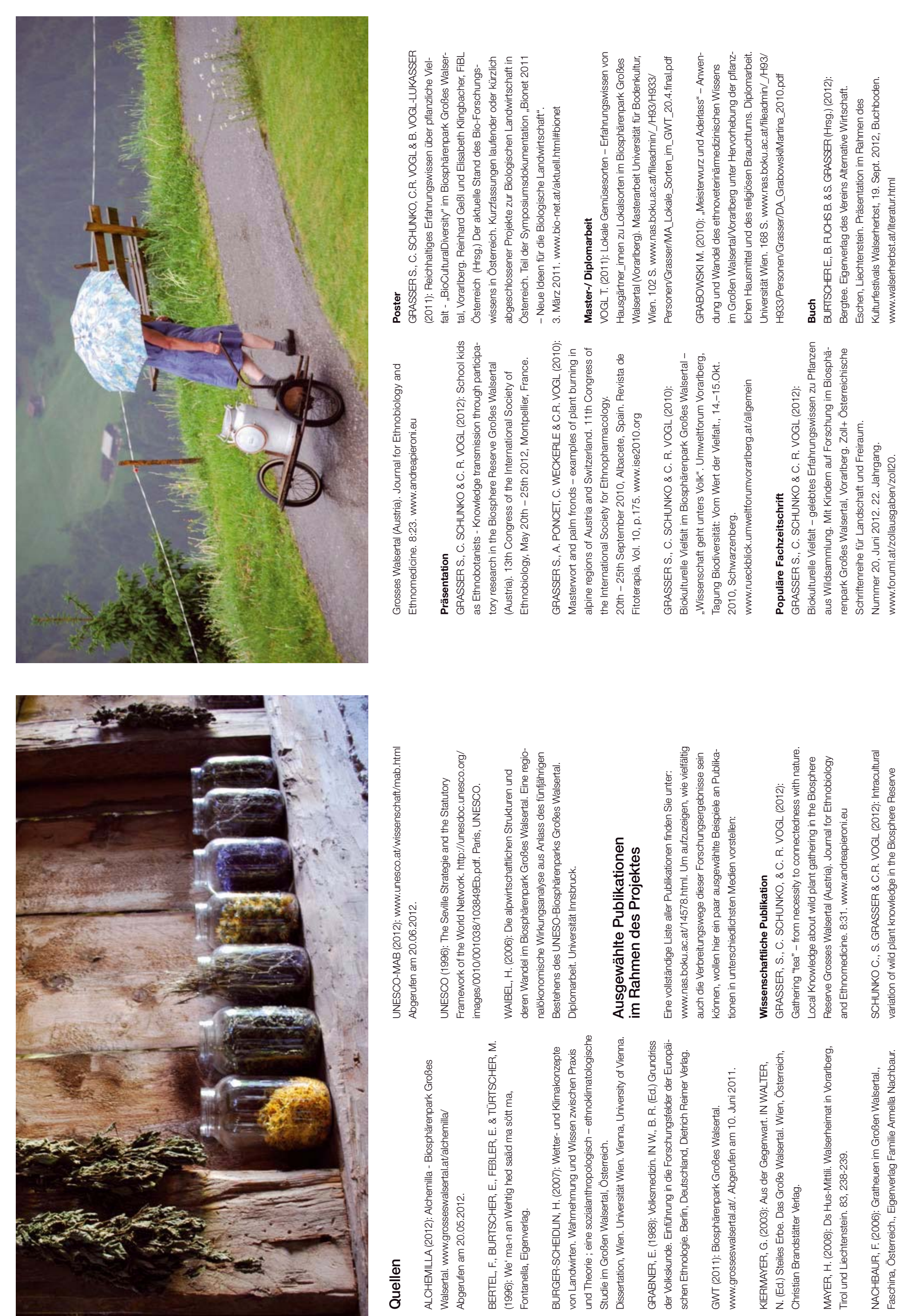


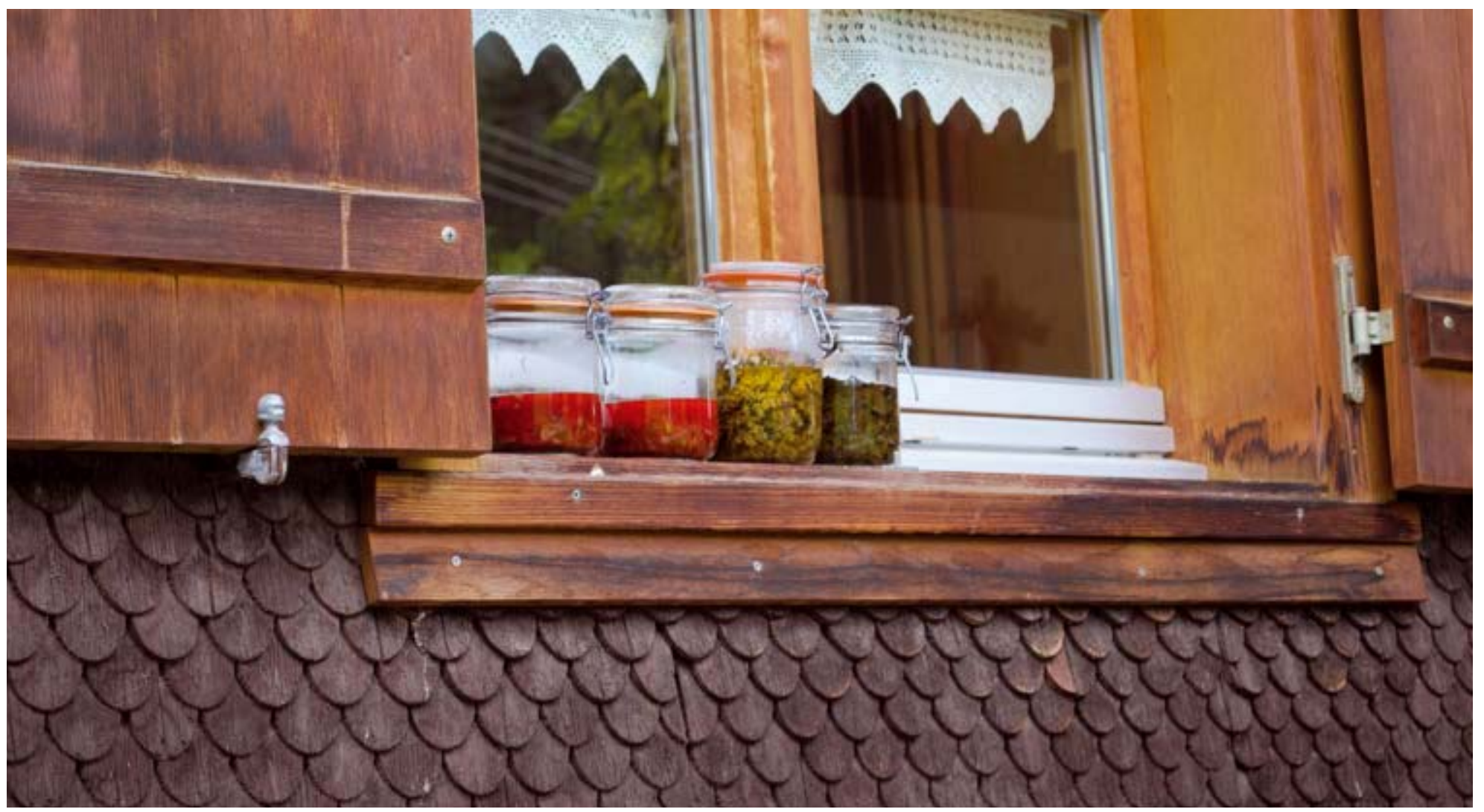

\section{Filme}

„Kraut im Bild“ - Kräuterdokumentarfilm der Volksschulkinder, St. Gerold, Mai 2010. 39 Min. unter der Anleitung von S. Grasser und M. Weber. Uraufführung im Rahmen des Kulturfestivals Walserherbst, 11.Sept.2010, St. Gerold. www.walserherbst.at/film.html

www.youtube.com/watch?v=pp3Fxp0V9Go

sowie weitere Teile unter www.youtube.com/user/oekoland

„Ein Zwerg kaut am Berg Kraut“ - Dokumentarisches Kräutermärchen der Kinder aus Fontanella, Sonntag, Blons, Thüringerberg und Raggal, Juli 2010. 45 Min. unter der Anleitung von S. Grasser und M. Weber. Uraufführung im Rahmen des Kulturfestivals Walserherbst, 11.Sept.2010, St. Gerold. www.walserherbst.at/film.html www.youtube.com/watch?v=Zg1CAGLXE9Y sowie weitere Teile unter www.youtube.com/user/oekoland

\section{Preis}

Umweltzeichen Projekt-Wettbewerb (2012): Hauptpreis für „Kraut im Bild - Kräuterdokumentarfilm der Volksschule St. Gerold“ unter der Leitung von S. Grasser und M. Weber (2010) im Rahmen des Forschungsprojektes „Biocultural Divesity Monitoring“.

\section{Berichte über das Projekt in Öffentlichen Nachrichten}

VN Vorarlberger Nachrichten - Heimat Bludenz (2010): Ein Zwerg kaut am Berg Kraut. Großwalsertaler Kids stellen sich als Filmemacher vor. 09.09.2010.

VN Vorarlberger Nachrichten - Bezirk Bludenz (2010): Kräutervielfalt in Bild \& Ton. 10.09.2010.

Vorarlberg heute (2010): Interview mit S. Grasser zum Projekt „Mensch \& Kraut in Bild und Ton“ im Rahmen des 10-jährigen Jubiläumsfestes des Biosphärenparks Großes Walsertal. 04.09.2010, Life-Übertragung um 19.00 Uhr.

sowie regelmäßige Berichterstattung zum Projekt-Fortschritt im Blickwinkel, Zeitschrift des Biosphärenparks Großes Walsertal (in den Ausgaben von 42/2008 bis 50/2010)

\section{Haftungsausschluss:}

Die Rezepte und Anwendungen der Hausmittel, die in diesem Bericht genannt sind, sind eine Wiedergabe von Aussagen von Gesprächspartnerinnen und Gesprächspartnern. Bei der Darstellung dieser Rezepte und Anwendungen in diesem Bericht handelt es sich weder um Empfehlungen noch um Bewertungen durch die Autorlnnen. Von den Autorlnnen wird keinerlei Haftung für die Folgen der Anwendung übernommen. 


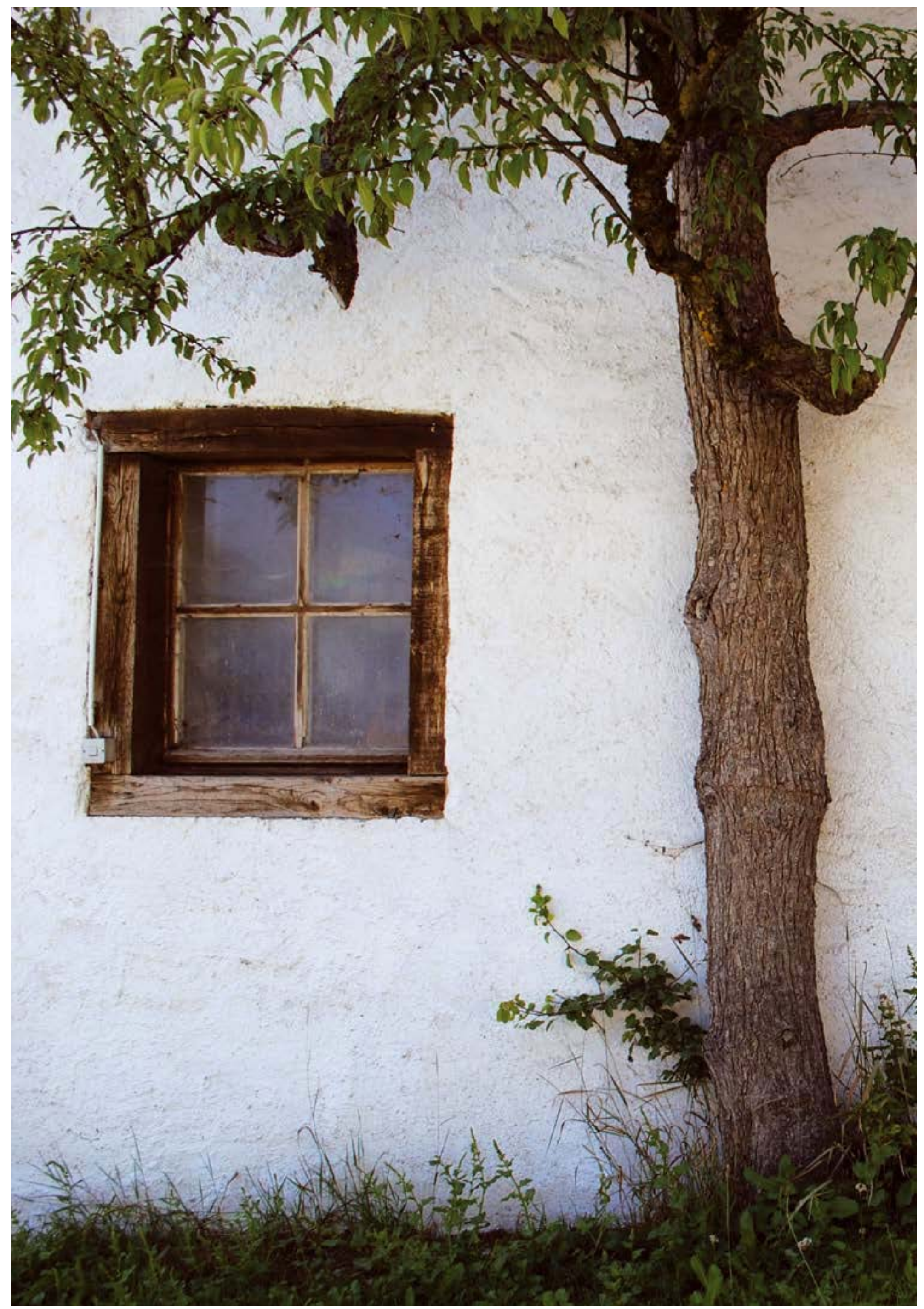




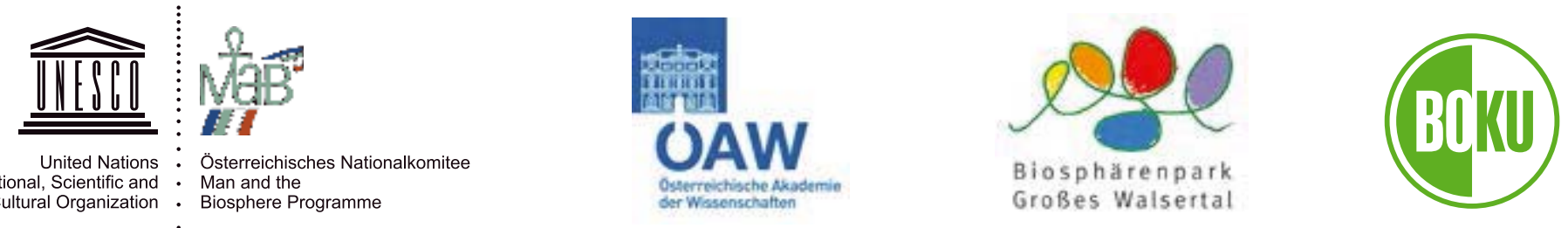

Cultural Organization . Biosphere Programme

Großes Walsertal
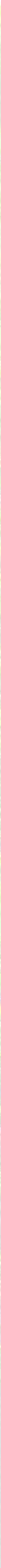